\title{
Sybodies targeting the SARS-CoV-2 receptor-binding domain
}

Justin D. Walter ${ }^{1, \#}$, Cedric A.J. Hutter ${ }^{1, \#}$, Iwan Zimmermann ${ }^{1,2}$, Marianne Wyss ${ }^{3}$, Jennifer Earp ${ }^{1}$, Pascal Egloff ${ }^{1,2}$, Michèle Sorgenfrei ${ }^{1}$, Lea M. Hürlimann ${ }^{1}$, Imre Gonda ${ }^{1}$, Gianmarco Meier ${ }^{1}$, Sille Remm ${ }^{1}$, Sujani Thavarasah ${ }^{1}$, Philippe Plattet ${ }^{3,}{ }^{,}$, Markus A. Seeger ${ }^{1,{ }^{*}}$

${ }^{1}$ Institute of Medical Microbiology, University of Zurich, Switzerland

${ }^{2}$ Linkster Therapeutics AG, Zurich, Switzerland

${ }^{3}$ Division of Experimental and Clinical Research, Vetsuisse Faculty, University of Bern, Switzerland

"Equal contribution

*Corresponding authors: philippe.plattet@vetsuisse.unibe.ch and m.seeger@imm.uzh.ch

\section{ABSTRACT}

The COVID-19 pandemic, caused by the novel coronavirus SARS-CoV-2, has resulted in a global health and economic crisis of unprecedented scale. The high transmissibility of SARS-CoV-2, combined with a lack of population immunity and prevalence of severe clinical outcomes, urges the rapid development of effective therapeutic countermeasures. Here, we report the generation of synthetic nanobodies, known as sybodies, against the receptor-binding domain (RBD) of SARS-CoV-2. In an expeditious process taking only twelve working days, sybodies were selected entirely in vitro from three large combinatorial libraries, using ribosome and phage display. We obtained six strongly enriched sybody pools against the isolated RBD and identified 63 unique anti-RBD sybodies which also interact in the context of the full-length SARS-CoV-2 spike ectodomain. Among the selected sybodies, six were found to bind to the viral spike with double-digit nanomolar affinity, and five of these also showed substantial inhibition of RBD interaction with human angiotensin-converting enzyme 2 (ACE2). Additionally, we identified a pair of anti-RBD sybodies that can simultaneously bind to the RBD. It is anticipated that compact binders such as these sybodies could feasibly be developed into an inhalable drug that can be used as a convenient prophylaxis against COVID-19. Moreover, generation of polyvalent antivirals, via fusion of anti-RBD sybodies to additional small binders recognizing secondary epitopes, could enhance the therapeutic potential and guard against escape mutants. We present full sequence information and detailed protocols for the identified sybodies, as a freely accessible resource. 


\section{INTRODUCTION}

The ongoing pandemic arising from the emergence of the 2019 novel coronavirus, SARS-CoV-2, demands urgent development of effective antiviral therapeutics. Several factors contribute to the adverse nature of SARS-CoV-2 from a global health perspective, including the absence of herd immunity [1], high transmissibility [2, 3], the prospect of asymptomatic carriers [4], and a high rate of clinically severe outcomes [5]. Moreover, a vaccine against SARS-CoV-2 is unlikely to be available for at least 12-18 months [6], despite earnest development efforts [7, 8], making alternative intervention strategies paramount. In addition to offering relief for patients suffering from the resulting COVID-19 disease, therapeutics may also reduce the viral transmission rate by being administered to asymptomatic individuals subsequent to probable exposure [9]. Finally, given that SARS-CoV-2 represents the third global coronavirus outbreak in the past 20 years $[10,11]$, development of rapid therapeutic strategies during the current crises could offer greater preparedness for future pandemics.

Akin to all coronaviruses, the viral envelope of SARS-CoV-2 harbors protruding, club-like, multidomain spike proteins that provide the machinery enabling entry into human cells [12-14]. The spike ectodomain is segregated into two regions, termed S1 and S2. The outer S1 subunit of SARS-CoV-2 is responsible for host recognition via interaction between its C-terminal receptor-binding domain (RBD) and human angiotensin converting enzyme 2 (ACE2), present on the exterior surface of airway cells $[14,15]$. While there is no known host-recognition role for the S1 N-terminal domain (NTD) of SARSCoV-2, it is notable that S1 NTDs of other coronaviruses have been shown to bind host surface glycans $[12,16]$. In contrast to spike region S1, the S2 subunit contains the membrane fusion apparatus, and also mediates trimerization of the ectodomain [12-14]. Prior to host recognition, spike proteins exist in a metastable pre-fusion state wherein the S1 subunits lay atop the S2 region and the RBD oscillates between "up" and "down" conformations that are, respectively, accessible and inaccessible to receptor binding $[12,17,18]$. Upon processing at the S1/S2 and S2' cleavage sites by host proteases as well as engagement to the receptor, the $\mathrm{S} 2$ subunit undergoes dramatic conformational changes from the pre-fusion to the post-fusion state. Such structural rearrangements are associated with the merging of the viral envelope with host membranes, thereby allowing injection of the genetic information into the cytoplasm of the host cell $[19,20]$.

Coronavirus spike proteins are highly immunogenic [21], and several experimental approaches have sought to target this molecular feature for the purpose of viral neutralization [22]. The high specificity, potency, and modular nature of antibody-based antiviral therapeutics has shown exceptional promise [23-25], and the isolated, purified RBD has been a popular target for the development of anti-spike antibodies against pathogenic coronaviruses [26-29]. However, binders against the isolated RBD may not effectively engage the aforementioned pre-fusion conformation of the full spike, which could account for the poor neutralization ability of recently described single-domain antibodies that were raised against the RBD of SARS-CoV-2 [30]. Therefore, to better identify molecules with qualities befitting a drug-like candidate, it would be advantageous to validate RBD-specific binders in the context of the full, stabilized, pre-fusion spike assembly [13, 31].

Single domain antibodies based on the variable VHH domain of heavy-chain-only antibodies of camelids - generally known as nanobodies - have emerged as a broadly utilized and highly successful antibody fragment format [32]. Nanobodies are small (12-15 kDa), stable, and inexpensive to produce in bacteria and yeast [33], yet they bind targets in a similar affinity range as conventional antibodies. Due to their minimal size, they are particularly suited to reach hidden epitopes such as crevices of 
target proteins [34]. We recently designed three libraries of synthetic nanobodies, termed sybodies, based on elucidated structures of nanobody-target complexes (Fig. 1A) [35, 36]. Sybodies can be selected against any target protein within twelve working days, which is considerably faster than natural nanobodies, which requires the repetitive immunization during a period of two months prior to binder selection by phage display [36] (Fig. 1C). A considerable advantage of our platform is that sybody selections are carried out under defined conditions - in case of coronavirus spike proteins, this offers the opportunity to generate binders recognizing the metastable pre-fusion conformation $[13,14]$. Finally, due to the feasibility of inhaled therapeutic nanobody formulations [37], virusneutralizing sybodies could offer a convenient and direct means of prophylaxis.

Here, we report of in vitro selection and characterization of sybodies against the RBD of SARS-CoV-2 spike protein. Two independently prepared RBD constructs were used for in vitro sybody selections, and resulting single clones that could bind the full spike ectodomain were sequenced, expressed, and purified. Six unique sybodies show favorable binding affinity to the SARS-CoV-2 spike, and five of these were also found to substantially attenuate the interaction between the viral RBD and human ACE2. Moreover, pairs of sybodies were identified that can simultaneously bind to the RBD. We present all sequences for these clones, along with detailed protocols to enable the community to freely produce and further characterize these SARS-CoV-2 binders.

\section{RESULTS AND DISCUSSION}

\section{Purification and biotinylation of target proteins}

Based on sequence alignments with isolated RBD variants from SARS-CoV-1 that were amenable to purification and crystallization [29, 38], a SARS-CoV-2 RBD construct was designed, consisting of residues Pro330-Gly526 fused to Venus YFP (RBD-vYFP). This construct was expressed and secreted from Expi293 cells, and RBD-vYFP was extracted directly from culture medium supernatant using an immobilized anti-GFP nanobody [39], affording a highly purified product with negligible background contamination. Initial efforts to cleave the $\mathrm{C}$-terminal vYFP fusion partner with $3 \mathrm{C}$ protease resulted in unstable RBD, so experiments were continued with full RBD-vYFP fusion protein. To account for the presence of the vYFP fusion partner, a second RBD construct, consisting of a fusion to murine IgG1 Fc domain (RBD-Fc), was commercially acquired. To remove any trace amines, buffers were exchanged to PBS via extensive dialysis. Proteins were chemically biotinylated, and the degree of biotinylation was assessed by a streptavidin gel-shift assay and found to be greater than $90 \%$ of the target proteins [40]. We note that while both RBD fusion proteins were well-behaved, a commercially acquired purified full-length SARS-CoV-2 spike ectodomain construct (ECD) was found to be aggregation-prone. Very recently, we also produced an engineered spike protein ectodomain containing two point mutations known to stabilize the pre-fusion state, an inactivated furin cleavage site, and a C-terminal trimerization motif $[13,14,31]$. While this purified pre-fusion spike (PFS) had not yet been available for binder selections and characterization by grating-coupled interferometry, it was used to conduct ELISAs in order to identify selected sybodies which recognize the RBD in the pre-fusion context (see below). 


\section{Sybody selections}

Since both our RBD constructs bear additional fusion domains ( $\mathrm{FC}$ of mouse IgG1 and VYFP, respectively), sybody selections were carried out with a "target swap" approach (Fig. 1B). Hence, selections with the three sybody libraries (concave, loop and convex) were started with the RBD-vYFP construct using ribosome display, and the RBD-Fc construct was then used for the two phage display rounds (selection variant 1: RBD-VYFP/RBD-Fc/RBD-Fc) and vice versa (selection variant 2: RBD-Fc/RBDVYFP/RBD-vYFP). Accordingly, there were a total of six selection reactions (Table 1, Fig. 1B). To increase the average affinity of the isolated sybodies, we included an off-rate selection step using the preenriched purified sybody pool after phage display round 1 as competitor. To this end, sybody pools of all three libraries of the same selection variant were sub-cloned from the phage display vectors into the sybody expression vector pSb_init. Subsequently, the two separate pools (all sybodies of selection variants 1 and 2, respectively) were expressed and purified. The purified pools were then added to the panning reactions of the respective selection variant in the second phage display round. Thereby, rebinding of sybody-phage complexes with fast off-rates was suppressed. Enrichment of sybodies against the RBD was monitored by qPCR. Already in the first phage display round, the concave and loop sybodies of selection variant 2 showed enrichment factors of 7 and 3 , respectively (Table 1 ). After the second phage display round (which included the off-rate selections step), strong enrichment factors in the range of 10-263 were determined.

\section{Sybody identification by ELISA}

After sub-cloning the pools from the phage display vector pDX_init into the sybody expression vector pSb_init, 47 clones of each of the 6 selections reactions (Table 1, Fig. 1B) were picked at random and expressed in small scale. Our standard ELISA was initially performed using RBD-vYFP (RBD), spike ectodomain containing S1 and S2 (ECD), and maltose binding protein (MBP) as unrelated dummy protein. As outlined in the Materials and Methods section, ELISA analysis revealed very high hit rates for the RBD and the ECD ranging from $81 \%$ to $100 \%$ and $66 \%$ to $96 \%$, respectively (Fig. 2, Table 1 ). The majority of the sybodies giving an ELISA signal to the RBD also gave a clear signal the full-length spike protein (Fig. 2). However, there was a total of 44 hits that only gave an ELISA signal for RBD-vYFP, but not for the ECD. This could be due to the presence of cryptic RBD epitopes that are not accessible in the context of the full-length spike protein, or the respective sybodies may recognize the vYFP portion of the RBD-VYFP construct, though the selection procedure clearly disfavors the latter explanation. Importantly, background binding to the dummy protein MBP was not observed for any of the analyzed sybodies, clearly showing that the binders are highly specific. We then sequenced 72 sybodies that were ELISA-positive against RBD-vYFP as well as the full-length spike (12 for each of the 6 selection reactions numbered from Sb\#1-72, see also Fig. 1B).

Subsequent to sybody sequencing, we also performed the ELISA using engineered pre-fusion-stabilized spike ectodomain (PFS) (Fig. 2), which was not available at the onset of the project. Overall, the ELISA signals for the ECD and PFS are highly similar. However, there are around 40 sybodies that bind to the ECD clearly stronger than to the PFS (yet the opposite scenario was never observed). This could be explained by the fact that the PFS forms a trimer, while the oligomeric state of the ECD is not clear. In addition, the ECD might adopt partially or completely a post-fusion state, whereas PFS is expected to predominantly adopt the pre-fusion state. Trimer formation as well as pre-fusion stabilization might shield certain binding epitopes on the RBD in the context of the PFS, which might become accessible 
as the spike falls apart into monomers and/or transits to the post-fusion state. In light of our ELISA data, the PFS construct will be a crucial element in any future sybody selection campaigns.

\section{Sequence analysis}

Sequencing results of 70 out of 72 sybody clones were unambiguous. Out of these 70 clones, 63 were found to be unique and the respective clone names are indicated in the ELISA figure (Fig. 2, Table 2). Of note, there were no duplicate binders identified in both selection variants, indicating that the two separate selection streams gave rise to completely different arrays of sybodies. As an additional note, one sybody identified from the supposed convex library turned out to belong to the concave library; spill-over of sybodies across libraries is occasionally observed. Hence, there was a total of 23 concave, 22 loop and 18 convex sybodies, which were then aligned according to their library origin (Figs. 3-5). As a final analysis, all sybody sequences were aligned to generate a phylogenetic tree, which shows a clear segregation across the three libraries and indicates a large sequence variability of the identified sybodies (Fig. 6).

\section{Purification of sybodies and kinetic analysis of sybody interaction with SARS-CoV-2 proteins}

The 63 unique sybodies were individually expressed in E. coli and purified via Ni-NTA affinity chromatography and gel filtration. Ultimately, 57 sybodies were sufficiently well-behaved, with respect to solubility, yield, and monodispersity, to proceed with further characterization. For a kinetic analysis of sybody interactions with the viral spike, we employed grating-coupled interferometry (GCI) to probe sybody binding to immobilized RBD-vYFP or ECD. First, the 57 purified sybodies were subjected to an off-rate screen, which revealed six sybodies (Sb\#14, Sb\#15, Sb\#16, Sb\#42, Sb\#45, and Sb\#68) with strong binding signals and comparatively slow off-rates. Binding constants were then determined by measuring on-and off-rates over a range of sybody concentrations, revealing affinities within a range of 20-180 nM to the SARS-CoV-2 spike (Fig. 7, Table 3). Of note, binding affinities were consistently equal or higher for the ECD as compared to the RBD-VYFP, in particular in case of Sb\#68 for which the off-rate differs by more than two-fold. This might indicate a binding avidity effect arising from binding epitopes clustering in the context of the spike trimer or differences with regards to the glycan structures (RBD-vYFP was produced in HEK cells, whereas the ECD was produced in insect cells). To our surprise, the majority of purified and ELISA-positive sybodies (51 out of 57) displayed binding affinities worse than $200 \mathrm{nM}$. This may be attributed to the presence of complex heterogeneous Asnlinked glycans within the RBD, which could hinder the isolation of specific high-affinity binders. Alternatively, given that the final ELISA step of the selection process resulted in a substantial number of positive clones, insufficiently stringent conditions may have favored the high positive hit rate of lowaffinity binders.

\section{ACE2 competition analysis}

Since virulence of SARS-CoV-2 is dependent on the ability of the viral RBD to bind to human ACE2 (hACE2), we sought to determine which of the 57 selected sybodies that were well-behaved upon purification could inhibit interaction between the isolated RBD and purified hACE2. For this assessment, ELISA plates were coated with purified hACE2, and the binding of purified RBD to the 
immobilized hACE2 was measured in the presence or absence of an excess of each purified sybody (Fig. 8). While the absence of any added sybody resulted in a strong ELISA signal corresponding to RBD association with hACE2, the pre-incubation of nearly all sybodies with the RBD resulted in an attenuated signal, implying that these binders inhibit RBD-hACE2 association. This signal decrease relative to unchallenged RBD was modest for most sybodies, with an average signal reduction of about $50 \%$, but five sybodies demonstrated exceptionally high apparent inhibition of RBD-hACE2 interaction (Sb\#14, Sb\#15, Sb\#16, Sb\#42, and Sb\#45), showing $290 \%$ signal reduction. Notably, the aforementioned kinetic analysis had shown that these sybodies were also among the strongest RBD binders. Taken together, this data suggests that Sb\#14, Sb\#15, Sb\#16, Sb\#42, and Sb\#45 recognize a surface region on the RBD that overlaps with the hACE2 binding site.

\section{Simultaneous binding of multiple sybodies to the RBD}

While kinetic analysis had revealed Sb\#68 to be among the stronger binders to the SARS-CoV-2 ectodomain ( $K_{D} \approx 37 \mathrm{nM}$, Fig. 7, Table 3), the hACE2 competition ELISA revealed that Sb\#68 does not inhibit hACE2-RBD interaction to the same extent as other sybodies with comparable affinities (65\% inhibition for Sb\#68, compared to $>90 \%$ for Sb\#14, Sb\#15, Sb\#16, and Sb\#45). Therefore, it was hypothesized that $\mathrm{Sb} \# 68$ may interact with a non- or partially-overlapping surface on the RBD, relative to the more strongly-inhibiting sybodies. Using Sb\#15 as a representative of the hACE2-inhibiting sybodies, we analyzed the ability of Sb\#15 and Sb\#68 to simultaneously associate with the RBD. First, ELISA experiments demonstrate that incubation of Sb\#68 with the pre-fusion spike only slightly prevents the spike from binding to immobilized Sb\#15, whereas pre-incubation with Sb\#14, Sb\#15, Sb\#16, Sb\#42, or Sb\#45 completely prevents spike interaction with immobilized Sb\#15 (Fig. 9). In agreement with the ELISA data, $\mathrm{GCl}$ experiments revealed that co-injection of Sb\#15 and Sb\#68 results in a clear (but not fully additive) increase of the response signal, relative to Sb\#15 or Sb\#68 injected alone, implying simultaneous binding of Sb\#15 and Sb\#68 (Fig. 9). The control GCl experiment involving the co-injection of Sb\#15 and Sb\#45 did not result in a similar signal increase (Fig. 9). In sum, this data plausibly suggests that Sb\#15 and Sb\#68 can simultaneously bind to the RBD. For the design of therapeutics against SARS-CoV-2, the fusion of such a pair of non-overlapping binders could provide benefits via increased overall avidity to the spike protein.

\section{Conclusion and outlook}

We have demonstrated the ability of our rapid in vitro selection platform to generate sybodies against the SARS-CoV-2 RBD, within a two-week timeframe. Characterization of these sybodies has identified a high-affinity subset of binders that also inhibit the RBD-ACE2 interaction. We anticipate that the presented panel of anti-RBD sybodies could be of use in the design of urgently required therapeutics to mitigate the COVID-19 pandemic, particularly in the development of inhalable prophylactic formulations [37]. Furthermore, our identification of a pair of sybodies that can simultaneously associate with the RBD may offer an attractive foundation for the construction of a polyvalent sybodybased therapeutic. We have attempted to provide a complete account of the generation of these molecules, including full sequences and detailed methods, such that other researchers may contribute to their ongoing analysis. Future work may include virus neutralization assays using the identified sybodies, as well as further selection campaigns targeting additional spike epitopes. Finally, our recently described flycode technology could be utilized for deeper interrogation of selection pools, in 
order to facilitate discovery of exceptional sybodies that possess very slow off-rates or recognize rare epitopes [41].

\section{METHODS}

\section{Cloning, expression and purification of SARS-CoV-2 proteins}

A gene encoding SARS-CoV-2 residues Pro330-Gly526 (RBD, GenBank accession QHD43416.1), downstream from a modified $\mathrm{N}$-terminal human serum albumin secretion signal [42], was chemically synthesized (GeneUniversal). This gene was subcloned using FX technology [43] into a custom mammalian expression vector [44], appending a C-terminal 3C protease cleavage site, myc tag, Venus YFP[45], and streptavidin-binding peptide [46] onto the open reading frame (RBD-vYFP). 100-250 mL of suspension-adapted Expi293 cells (Thermo) were transiently transfected using Expifectamine according to the manufacturer protocol (Thermo), and expression was continued for 4-5 days in a humidified environment at $37^{\circ} \mathrm{C}, 8 \% \mathrm{CO}_{2}$. Cells were pelleted $(500 \mathrm{~g}, 10 \mathrm{~min})$, and culture supernatant was filtered $(0.2 \mu \mathrm{m}$ mesh size) before being passed three times over a gravity column containing NHSagarose beads covalently coupled to the anti-GFP nanobody 3K1K [39], at a resin:culture ratio of $1 \mathrm{ml}$ resin per $100 \mathrm{ml}$ expression culture. Resin was washed with 20 column-volumes of RBD buffer (phosphate-buffered saline, $\mathrm{pH} 7.4$, supplemented with additional $0.2 \mathrm{M} \mathrm{NaCl}$ ), and RBD-vYFP was eluted with $0.1 \mathrm{M}$ glycine, $\mathrm{pH} 2.5$, via sequential $0.5 \mathrm{ml}$ fractions, without prolonged incubation of resin with the acidic elution buffer. Fractionation tubes were pre-filled with $1 / 10$ vol $1 \mathrm{M}$ Tris, $\mathrm{pH} 9.0(50 \mu \mathrm{l})$, such that elution fractions were immediately $\mathrm{pH}$-neutralized. Fractions containing RBD-vYFP were pooled, concentrated, and stored at $4^{\circ} \mathrm{C}$. Purity was estimated to be $>95 \%$, based on SDS-PAGE (not shown). Yield of RBD-vYFP was approximately 200-300 $\mu \mathrm{g}$ per $100 \mathrm{ml}$ expression culture. A second purified RBD construct, consisting of SARS-CoV-2 residues Arg319-Phe541 fused to a murine IgG1 Fc domain (RBD-Fc) expressed in HEK293 cells, was purchased from Sino Biological (Catalogue number: 40592-V05H, $300 \mu \mathrm{g}$ were ordered). Purified full-length spike ectodomain (ECD) comprising S1 and S2 (residues Val16-Pro1213) with a C-terminal His-tag and expressed in baculovirus-insect cells was purchased from Sino Biological (Catalogue number: 40589-V08B1, $700 \mu \mathrm{g}$ were ordered). The prefusion ectodomain of the SARS-CoV2 Spike protein (residues 1-1208) [13], was transiently transfected into $50 \times 10^{8}$ suspension-adapted ExpiCHO cells (Thermo Fisher) using $3 \mathrm{mg}$ plasmid DNA and $15 \mathrm{mg}$ of PEI MAX (Polysciences) per $1 \mathrm{~L}$ ProCHO5 medium (Lonza) in a $3 \mathrm{~L}$ Erlenmeyer flask (Corning) in an incubator shaker (Kühner). One hour post-transfection, dimethyl sulfoxide (DMSO; AppliChem) was added to $2 \%(\mathrm{v} / \mathrm{v})$. Incubation with agitation was continued at $31^{\circ} \mathrm{C}$ for 5 days. $1 \mathrm{~L}$ of filtered $(0.22 \mathrm{um})$ cell culture supernatant was clarified. Then, a $1 \mathrm{~mL}$ Gravity flow Strep-Tactin ${ }^{\circledR} \mathrm{XT}$ Superflow ${ }^{\circledast}$ column (iba lifescience) was rinsed with $2 \mathrm{ml}$ buffer $\mathrm{W}(100 \mathrm{mM}$ Tris, $\mathrm{pH} 8.0,100 \mathrm{mM} \mathrm{NaCl}$, $1 \mathrm{mM}$ EDTA) using gravity flow. The supernatant was added to the column, which was then rinsed with $5 \mathrm{ml}$ of buffer $\mathrm{W}$ (all with gravity flow). Finally, six elution steps were performed by adding each time $0.5 \mathrm{ml}$ of buffer BXT ( $50 \mathrm{mM}$ Biotin in buffer $\mathrm{W}$ ) to the resin. All purification steps were performed at $4^{\circ} \mathrm{C}$.

\section{Biotinylation of target proteins}

To remove amines, all proteins were first extensively dialyzed against RBD buffer. Proteins were concentrated to $25 \mu \mathrm{M}$ using Amicon Ultra concentrator units with a molecular weight cutoff of $30-$ 
$50 \mathrm{kDa}$. Subsequently, the proteins were chemically biotinylated for $30 \mathrm{~min}$ at $25^{\circ} \mathrm{C}$ using NHS-Biotin (Thermo Fisher, \#20217) added at a 10-fold molar excess over target protein. Immediately after, the three samples were dialyzed against TBS pH 7.5. During these processes (first dialysis/ concentrating/ biotinylation/ second dialysis), $20 \%, 30 \%, 65 \%$ and $44 \%$ of the RBD-VYFP, RBD-Fc, ECD and PFS respectively were lost due to sticking to the concentrator filter or due to aggregation. Biotinylated RBD-VYFP, RBD-FC and ECD were diluted to $5 \mu \mathrm{M}$ in TBS pH 7.5, $10 \%$ glycerol and stored in small aliquots at $-80^{\circ} \mathrm{C}$. Biotinylated PFS was stored at $4^{\circ} \mathrm{C}$ in TBS $\mathrm{pH} 7.5$.

\section{Sybody selections}

Sybody selections with the three sybody libraries concave, loop and convex were carried out as described in detail before [36]. In short, one round of ribosome display followed by two rounds of phage display were carried out. Binders were selected against two different constructs of the SARSCoV-2 RBD; an RBD-vYFP fusion and an RBD-Fc fusion. MBP was used as background control to determine the enrichment score by qPCR [36]. In order to avoid enrichment of binders against the fusion proteins (YFP and Fc), we switched the two targets after ribosome display (Fig. 1B). For the offrate selections we did not use non-biotinylated target proteins as described in the standard protocol, because we did not have enough purified protein at hand to do so. Instead we sub-cloned all three libraries for both selections after the first round of phage display into the pSb_init vector ( $10^{8}$ clones) and expressed the six pools in E. coli MC1061 cells. Then the pools corresponding to the same selection were pooled for purification. The two final pools were purified by Ni-NTA resin using gravity flow columns, followed by buffer exchange of the main peak fraction using a desalting PD10 column in TBS $\mathrm{pH} 7.5$ to remove imidazole. The pools were eluted with $3.2 \mathrm{ml}$ instead of $3.5 \mathrm{ml} \mathrm{TBS} \mathrm{pH} 7.5$ in order to ensure complete buffer exchange. These two purified pools were used for the off-rate selection in the second round of phage display at concentrations of approximately $390 \mu \mathrm{M}$ for selection variant 1 (RBP-Fc) and $450 \mu \mathrm{M}$ for selection variant 2 (RBP-YFP). The volume used for off-rate selection was 500 $\mu \mathrm{l}$. Just before the pools were used for the off-rate selection, $0.5 \%$ BSA and $0.05 \%$ Tween-20 was added to each sample. Off-rate selections were performed for 3 minutes.

\section{Sybody identification by ELISA}

ELISAs were performed as described in detail before [36]. 47 single clones were analyzed for each library of each selection. Since the RBD-Fc construct was incompatible with our ELISA format due to the inclusion of Protein A to capture an $\alpha$-myc antibody, ELISA was performed only for the RBD-vYFP ( $50 \mathrm{nM})$ and the ECD $(25 \mathrm{nM})$ and later on with the PFS (25 nM). Of note, the three targets were analyzed in three separate ELISAs. As negative control to assess background binding of sybodies, we used biotinylated MBP ( $50 \mathrm{nM}$ ). 72 positive ELISA hits were sequenced (Microsynth, Switzerland).

\section{Expression and Purification of sybodies}

The 63 unique sybodies were expressed and purified as described [36]. In short, all 63 sybodies were expressed overnight in E.coli MC1061 cells in $50 \mathrm{ml}$ cultures. The next day the sybodies were extracted from the periplasm and purified by Ni-NTA affinity chromatography (batch binding) followed by sizeexclusion chromatography using a Sepax SRT-10C SEC100 size-exclusion chromatography (SEC) column 
equilibrated in TBS, pH 7.5, containing $0.05 \%(\mathrm{v} / \mathrm{v})$ Tween-20 (detergent was added for subsequent kinetic measurements). Six out of the 63 binders (Sb\#4, Sb\#7, Sb\#18, Sb\#34, Sb\#47, Sb\#61) were excluded from further analysis due to suboptimal behavior during SEC analysis (i.e. aggregation or excessive column matrix interaction).

\section{Grating-coupled interferometry (GCI)}

Kinetic characterization of sybodies binding onto SARS-CoV-2 spike proteins was performed using GCI on the WAVEsystem (Creoptix AG, Switzerland), a label-free biosensor. Biotinylated RBD-VYFP and ECD were captured onto a Streptavidin PCP-STA WAVEchip (polycarboxylate quasi-planar surface; Creoptix AG) to a density of $1300-1800 \mathrm{pg} / \mathrm{mm}^{2}$. Sybodies were first analyzed by an off-rate screen performed at a concentration of $200 \mathrm{nM}$ (data not shown) to identify binders with sufficiently high affinities. The six sybodies Sb\#14, Sb\#15, Sb\#16, Sb\#42, Sb\#45, and Sb\#68 were then injected at increasing concentrations ranging from $1.37 \mathrm{nM}$ to $1 \mu \mathrm{M}$ (three-fold serial dilution, 7 concentrations) in TBS buffer supplemented with $0.05 \%$ Tween-20. Sybodies were injected for $120 \mathrm{~s}$ at a flow rate of $30 \mu \mathrm{l} / \mathrm{min}$ per channel and dissociation was set to $600 \mathrm{~s}$ to allow the return to baseline. Sensorgrams were recorded at $25{ }^{\circ} \mathrm{C}$ and the data analyzed on the WAVEcontrol (Creoptix AG). Data were double-referenced by subtracting the signals from blank injections and from the reference channel. A Langmuir 1:1 model was used for data fitting.

\section{ACE2 competition ELISA}

Purified recombinant hACE2 protein (MyBioSource, Cat\# MBS8248492) was diluted to $10 \mathrm{nM}$ in phosphate-buffered saline (PBS), $\mathrm{pH}$ 7.4, and $100 \mu \mathrm{l}$ aliquots were incubated overnight on Nunc MaxiSorp 96-well ELISA plates (ThermoFisher \#44-2404-21) at $4^{\circ} \mathrm{C}$. ELISA plates were washed three times with $250 \mu \mathrm{l}$ TBS containing $0.05 \%(\mathrm{v} / \mathrm{v})$ Tween-20 (TBST). Plates were blocked with $250 \mu \mathrm{l}$ of $0.5 \%$ $(\mathrm{w} / \mathrm{v}) \mathrm{BSA}$ in TBS for $2 \mathrm{~h}$ at room temperature. $100 \mu$ samples of biotinylated RBD-vYFP ( $25 \mathrm{nM}$ ) mixed with individual purified sybodies $(500 \mathrm{nM}$ ) were prepared in TBS containing $0.5 \%(\mathrm{w} / \mathrm{v}) \mathrm{BSA}$ and $0.05 \%$ $(\mathrm{v} / \mathrm{v})$ Tween-20 (TBS-BSA-T) and incubated for $1.5 \mathrm{~h}$ at room temperature. These $100 \mu \mathrm{l}$ RBD-sybody mixtures were transferred to the plate and incubated for 30 minutes at room temperature. $100 \mu \mathrm{l}$ of streptavidin-peroxidase (Merck, Cat\#S2438) diluted 1:5000 in TBS-BSA-T was incubated on the plate for $1 \mathrm{~h}$. Finally, to detect bound biotinylated RBD-vYFP, $100 \mu \mathrm{l}$ of development reagent containing 3,3',5,5'-Tetramethylbenzidine (TMB), prepared as previously described [36], was added, color development was quenched after 3-5 min via addition of $100 \mu \mathrm{l} 0.2 \mathrm{M}$ sulfuric acid, and absorbance at $405 \mathrm{~nm}$ was measured. Background-subtracted absorbance values were normalized to the signal corresponding to RBD-vYFP in the absence of added sybodies.

\section{Dual-sybody competition ELISA}

Purified sybodies carrying a C-terminal myc-His Tag (Sb_init expression vector) were diluted to $25 \mathrm{nM}$ in $100 \mu \mathrm{l} \mathrm{PBS} \mathrm{pH} 7.4$ and directly coated on Nunc MaxiSorp 96-well plates (ThermoFisher \#44-2404-21) at $4^{\circ} \mathrm{C}$ overnight. The plates were washed once with $250 \mu \mathrm{lTBS} \mathrm{pH} 7.5$ per well followed by blocking with $250 \mu \mathrm{l} \mathrm{TBS} \mathrm{pH} 7.5$ containing $0.5 \%$ (w/v) BSA per well. In parallel, chemically biotinylated prefusion Spike protein (PFS) at a concentration of $10 \mathrm{nM}$ was incubated with $500 \mathrm{nM}$ sybodies for $1 \mathrm{~h}$ at room 
bioRxiv preprint doi: https://doi org/10.1101/2020.04 16.045419 : this version posted May 16 2020. The copyright holder for this preprin (which was not certified by peer review) is the author/funder, who has granted bioRxiv a license to display the preprint in perpetuity. It is made available under aCC-BY 4.0 International license.

temperature in TBS-BSA-T. The plates were washed three times with $250 \mu \mathrm{l} \mathrm{TBS-T}$ per well. Then, 100 $\mu \mathrm{l}$ of the PFS-sybody mixtures were added to the corresponding wells and incubated for $3 \mathrm{~min}$, followed by washing three times with $250 \mu$ IBS-T per well. $100 \mu$ l Streptavidin-peroxidase polymer (Merck, Cat\#S2438) diluted 1:5000 in TBS-BSA-T was added to each well and incubated for $10 \mathrm{~min}$, followed by washing three times with $250 \mu$ I TBS-T per well. Finally, to detect PFS bound to the immobilized sybodies, $100 \mu \mathrm{l}$ ELISA developing buffer (prepared as described previously [36]) was added to each well, incubated for $1 \mathrm{~h}$ (due to low signal) and absorbance was measured at $650 \mathrm{~nm}$. As a negative control, TBS-BSA-T devoid of protein was added to the corresponding wells instead of a PFSsybody mixture.

\section{TABLES}

Table 1 -Key parameters of selection process

\begin{tabular}{|l|l|l|l|l|}
\hline $\begin{array}{l}\text { Selection } \\
\text { variant/library }\end{array}$ & $\begin{array}{l}\text { Enrichment } \\
\text { Phage } \\
\text { display\#1 }\end{array}$ & $\begin{array}{l}\text { Enrichment } \\
\text { Phage } \\
\text { display\#2 }\end{array}$ & $\begin{array}{l}\text { Number of ELISA hits } \\
\text { against RBD/ECD/PFS } \\
\text { (out of total analyzed) }\end{array}$ & $\begin{array}{l}\text { Number of unique } \\
\text { binders (out of total } \\
\text { sequenced) }\end{array}$ \\
\hline $\begin{array}{l}\text { Variant 1 } \\
\text { vYFP-Fc-Fc }\end{array}$ & & & & \\
\hline Concave (Sb\#1-12) & 1.8 & 204.9 & $46 / 45 / 39(47)$ & $12(12)$ \\
\hline Loop (Sb\#25-36) & 1.5 & 52.5 & $46 / 33 / 25(47)$ & $12(12)$ \\
\hline Convex (Sb\#49-60) ${ }^{1)}$ & 1.3 & 10.1 & $38 / 31 / 27(47)$ & $9(12)$ \\
\hline $\begin{array}{l}\text { Variant 2 } \\
\text { Fc-vYFP-vYFP }\end{array}$ & & & & \\
\hline Concave (Sb\#13-24) & 7.0 & 263.1 & $47 / 37 / 34(47)$ & $10(12)^{2)}$ \\
\hline Loop (Sb\#37-48) & 3.0 & 44.9 & $44 / 36 / 35(47)$ & $10(12)$ \\
\hline Convex (Sb\#61-72) & 1.2 & 47.7 & $46 / 41 / 41(47)$ & $10(12)$ \\
\hline
\end{tabular}

1) Sb\#51 belongs to the concave library (spill-over). ${ }^{2)}$ Two sequencing reactions failed.

Table 2-Sybody protein sequences

\begin{tabular}{|l|l|}
\hline Sb\# 1 & $\begin{array}{l}\text { QVQLVESGGGLVQAGGSLRLSCAASGFPVRKANMHWYRQAPGKEREWVAAIMSKGEQTVYADSVE } \\
\text { GRFTISRDNAKNTVYLQMNSLKPEDTAVYYCRVFVGWHYFGQGTQVTVS }\end{array}$ \\
\hline Sb\#2 & $\begin{array}{l}\text { QVQLVESGGGLVQAGGSLRLSCATSGFPVYQANMHWYRQAPGKEREWVAAIQSYGDGTHYADSVK } \\
\text { GRFTISRDNAKNTVYLQMNSLKPEDTAVYYCRAVYVGMHYFGQGTQVTVS }\end{array}$ \\
\hline Sb\#3 & $\begin{array}{l}\text { QVQLVESGGGLVQAGGSLRLSCAASGFPVNYKTMWWYRQAPGKEREWVAAIWSYGHTTHYADSVK } \\
\text { GRFTISRDNAKNTVYLQMNSLKPEDTAVYYCVVWVGHNYEGQGTQVTVS }\end{array}$ \\
\hline Sb\#4 & QVQLVESGGGLVQAGGSLRLSCAASGFPVYAQNMHWYRQAPGKEREWVAAIYSHGYWTLYADSVK \\
GRFTISRDNAKNTVYLQMNSLKPEDTAVYYCEVQVGAWYTGQGTQVTVS
\end{tabular}


bioRxiv preprint doi: https://doi org/10.1101/2020.04.16.045419; this version posted May 16, 2020. The copyright holder for this preprint (which was not certified by peer review) is the author/funder, who has granted bioRxiv a license to display the preprint in perpetuity. It is made available under aCC-BY 4.0 International license.

\begin{tabular}{|c|c|}
\hline Sb\# 8 & $\begin{array}{l}\text { QVQLVESGGGLVQAGGSLRLSCAASGFPVNAGNMHWYRQAPGKEREWVAAIQSYGRTTYYADSVK } \\
\text { GRFTISRDNAKNTVYLQMNSLKPEDTAVYYCRVFVGMHYFGQGTQVTVS }\end{array}$ \\
\hline Sb\# 9 & $\begin{array}{l}\text { QVQLVESGGGLVQAGGSLRLSCAASGFPVSSSTMTWYRQAPGKEREWVAAINSYGWETHYADSVK } \\
\text { GRETISRDNAKNTVYLQMNSLKPEDTAVYYCYVYVGGSYIGQGTQVTVS }\end{array}$ \\
\hline Sb\# 10 & $\begin{array}{l}\text { QVQLVESGGGLVQAGGSLRLSCAASGFPVQSHYMRWYRQAPGKEREWVAAIESTGHHTAYADSVK } \\
\text { GRFTISRDNAKNTVYLQMNSLKPEDTAVYYCTVYVGYEYHGQGTQVTVS }\end{array}$ \\
\hline Sb\# 11 & $\begin{array}{l}\text { QVQLVESGGGLVQAGGSLRLSCAASGFPVETENMHWYRQAPGKEREWVAAIYSHGMWTAYADSVK } \\
\text { GRETISRDNTKNTVYLQMNSLKPEDTAVYYCEVEVGKWYFGQGTQVTVS }\end{array}$ \\
\hline Sb\# 12 & $\begin{array}{l}\text { QVQLVESGGGLVQAGGSLRLSCAASGFPVKASRMYWYRQAPGKEREWVAAIQSFGEVTWYADSVK } \\
\text { GRFTISRDNAKNTVYLQMNSLKPEDTAVYYCYVWVGQEYWGQGTQVTVS }\end{array}$ \\
\hline Sb\#13 & $\begin{array}{l}\text { QVQLVESGGGLVQAGGSLRLSCAASGFPVYASNMHWYRQAPGKEREWVAAIESQGYMTAYADSVK } \\
\text { GRETISRDNAKNTVYLQMNSLKPEDTAVYYCWVIVGEYYVGQGTQVTVS }\end{array}$ \\
\hline Sb\#14 & $\begin{array}{l}\text { QVQLVESGGGLVQAGGSLRLSCAASGFPVQAREMEWYRQAPGKEREWVAAIKSTGTYTAYAYSVK } \\
\text { GRFTISRDNAKNTVYLQMNSLKPEDTAVYYCYVYVGSSYIGQGTQVTVS }\end{array}$ \\
\hline Sb\#15 & $\begin{array}{l}\text { QVQLVESGGGLVQAGGSLRLSCAASGFPVKNEEMEWYRKAPGKEREWVAAIQSGGVETYYADSVK } \\
\text { GRETISRDNAKNTVYLQMNSLKPEDTAVYYCFVYVGRSYIGQGTQVTVS }\end{array}$ \\
\hline Sb\# 16 & $\begin{array}{l}\text { QVQLVESGGGLVQAGGSLRLSCAASGFPVAYKTMWWYRQAPGKEREWVAAIESYGIKWTRYADSV } \\
\text { KGRFTISRDNAKNTVYLQMNSLKPEDTAVYYCIVWVGAQYHGQGTQVTVS }\end{array}$ \\
\hline Sb\# 17 & $\begin{array}{l}\text { QVQLVESGGGLVQAGGSLRLSCAASGFPVAGRNMWWYRQAPGKEREWVAAIYSSGTYTEYADSVK } \\
\text { GRFTISRDNAKNTVYLQMNSLKPEDTAVYYCHVWVGSLYKGQGTQVTVS }\end{array}$ \\
\hline Sb\#18 & $\begin{array}{l}\text { QVQLVESGGGLVQAGGSLRLSCAASGFPVKHARMWWYRQAPGKEREWVAAIDSHGDTTWYADSVK } \\
\text { GRETISRDNAKNTVYLQMNSLKPEDTAVYYCYVYVGASYWGQGTQVTVS }\end{array}$ \\
\hline Sb\# 19 & $\begin{array}{l}\text { QVQLVESGGGLVQAGGSLRLSCAASGFPVNSHEMTWYRQAPGKEREWVAAIQSTGTVTEYADSVK } \\
\text { GRFTISRDNAKNTVYLQMNSLKPEDTAVYYCYVYVGSSYLGQGTQVTVS }\end{array}$ \\
\hline Sb\#20 & $\begin{array}{l}\text { QVQLVESGGGLVQAGGSLRLSCAASGFPVEQREMEWYRQAPGKEREWVAAIDSNGNYTFYADSVK } \\
\text { GRETISRDNAKNTVYLQMNSLKPEDTAVYYCYVYVGKSYIGQGTQVTVS }\end{array}$ \\
\hline Sb\# 21 & $\begin{array}{l}\text { QVQLVESGGGLVQAGGSLRLSCAASGFPVKHHWMFWYRQAPGKEREWVAAIKSYGYGTEYADSVK } \\
\text { GRFTISRDNAKNTVYLQMNSLKPEDTAVYYCFVGVGTHYAGQGTQVTVS }\end{array}$ \\
\hline Sb\#23 & $\begin{array}{l}\text { QVQLVESGGGLVQAGGSLRLSCAASGFPVYAAEMEWYRQAPGKEREWVAAISSQGTITYYADSVK } \\
\text { GRETISRDNAKNTVYLQMNSLKPEDTAVYYCFVYVGKSYIGQGTQVSVS }\end{array}$ \\
\hline Sb\#25 & $\begin{array}{l}\text { QVQLVESGGGLVQAGGSLRLSCAASGFPVHAWEMAWYRQAPGKEREWVAAIRSFGSSTHYADSVK } \\
\text { GRFTISRDNAKNTVYLQMNSLKPEDTAVYYCNVKDFGTHHYAYDYWGQGTQVTVS }\end{array}$ \\
\hline Sb\#26 & $\begin{array}{l}\text { QVQLVESGGGLVQAGGSLRLSCAASGFPVNTWWMHWYRQAPGKEREWVAAITSWGFRTYYADSVK } \\
\text { GRFTISRDNAKNTVYLQMNSLKPEDTAVYYCNVKDKGMAVQWYDYWGQGTQVTVS }\end{array}$ \\
\hline Sb\# 27 & $\begin{array}{l}\text { QVQLVESGGGLVQAGGSLRLSCAASGFPVYNTWMEWYRQAPGKEREWVAAITSHGYKTYYADSVK } \\
\text { GRFTISRDNAKNTVYLQMNSLKPEDTAVYYCNVKDEGDMFTAYDYWGQGTQVTVS }\end{array}$ \\
\hline Sb\# 28 & $\begin{array}{l}\text { QVQLVESGGGLVQAGGSLRLSCAASGFPVYHSTMFWYRQAPGKEREWVAAIYSSGQHTYYADSVK } \\
\text { GRETISRDNAKNTVYLQMNSLKPEDTAVYYCNVKDSGQWRQEYDYWGQGTQVTVS }\end{array}$ \\
\hline Sb\#29 & $\begin{array}{l}\text { QVQLVESGGGLVQAGGSLRLSCAASGFPVEHEMAWYRQAPGKEREWVAAIRSMGRKTLYADSVKG } \\
\text { RFTISRDNAKNTVYLQMNSLKPEDTAVYYCNVKDFGYTWHEYDYWGQGTQVTVS }\end{array}$ \\
\hline Sb\#30 & $\begin{array}{l}\text { QVQLVESGGGLVQAGGSLRLSCAASGFPVTMAWMWWYRQAPGKEREWVAAIRSEGVRTYYADSVK } \\
\text { GRFTISRDNAKNTVYLQMNSLKPEDTAVYYCNVKDYGQAHAYYDYWGQGTQVTVS }\end{array}$ \\
\hline Sb\#31 & $\begin{array}{l}\text { QVQLVESGGGLVQAGGSLRLSCAASGFPVNSHFMEWYRQAPGKEREWVAAIQHSSGFHTYYADSV } \\
\text { KGRFTISRDNAKNTVYLQMNSLKPEDTAVYYCNVKDTGTTEDYDYWGQGTQVTVS }\end{array}$ \\
\hline Sb\#32 & $\begin{array}{l}\text { QVQLDESGGGLVQAGGSLRLSCAASGFPVYHAWMEWYRQAPGKEREWVAAITSSGRHTYYADSVK } \\
\text { GRFTISRDNAKNTVYLQMNSLKPEDTAVYYCNVKDAGRVYNSYDYWGQGTQVTVS }\end{array}$ \\
\hline Sb\#33 & $\begin{array}{l}\text { QVQLVESGGGLVQAGGSLRLSCAASGFPVAHAWMEWYRQAPGKEREWVAAITSYGYKTYYADSVK } \\
\text { GRFTISRDNAKNTVYLQMNSLKPEDTAVYYCNVKDTGTYRFYYDYWGQGTQVTVS }\end{array}$ \\
\hline Sb\# 34 & $\begin{array}{l}\text { QVQLVESGGGLVQAGGSLRLSCAASGFPVWNQTMVWYRQAPGKEREWVAAIWSMGHTYYADSVKG } \\
\text { RFTISRDNAKNTVYLQMNSLKPEDTAVYYCNVKDAGVYNRYYDYWGQGTQVTVS }\end{array}$ \\
\hline Sb\#35 & $\begin{array}{l}\text { QVQLVESGGGLVQAGGSLRLSCAASGFPVEHYWMEWYRQAPGKEREWVAAITSFGYRTYYADSVK } \\
\text { GRFTISRDNAKNTVYLQMNSLKPEDTAVYYCNVKDWGFASHAYDYWGQGIQVTVS }\end{array}$ \\
\hline
\end{tabular}


bioRxiv preprint doi: https://doi org/10.1101/2020.04 16.045419; this version posted May 16, 2020. The copyright holder for this preprint (which was not certified by peer review) is the author/funder, who has granted bioRxiv a license to display the preprint in perpetuity. It is made available under aCC-BY 4.0 International license.

\begin{tabular}{|c|c|}
\hline $\mathrm{Sb \# 36}$ & $\begin{array}{l}\text { QVQLVESGGGLVQAGGSLRLSCAASGFPEIAWEMAWYRQAPGKEREWVAAIRSFGERTLYADSVK } \\
\text { GRFTISRDNAKNTVYLQMNSLKPEDTAVYYCNVKDFGWQHQEYDYWGQGTQVTVS }\end{array}$ \\
\hline Sb\#37 & $\begin{array}{l}\text { QVQLVESGGGLVQAGGSLRLSCAASGFPVYHAYMEWYRQAPGKEREWVAAIYSNGEHTYYADSVK } \\
\text { GRFTISRDNAKNTVYLQMNSLKPEDTAVYYCNVKDSGSFNQAYDYWGQGTQVTVS }\end{array}$ \\
\hline Stb\#38 & $\begin{array}{l}\text { QVQLVESGGGLVQAGGSLRLSCAASGFPVEWSHMHWYRQAPGKEREWVAAIVSKGGYTLYADSVK } \\
\text { GRFTISRDNAKNTVYLQMNSLKPEDTAVYYCNVKDYGVHFKRYDYWGQGTQVTVI }\end{array}$ \\
\hline Stb\#39 & $\begin{array}{l}\text { QVQLVESGGGLVQAGGSLRLSCAASGFPVFHVWMEWYRQAPGKEREWVAAIDSAGWHTYYADSVK } \\
\text { GRFTISRDNAKNTVYLQMNSLKPEDTAVYYCNVKDAGNTTSAYDYWGQGTQVTVS }\end{array}$ \\
\hline $\mathrm{Sb \# 40}$ & $\begin{array}{l}\text { QVQLVESGGGLVQAGGSLRLSCAASGFPVYYNWMEWYRQAPGKEREWVAA I HSNGDETFYADSVK } \\
\text { GRFTISRDNAKNTVYLQMNSLKPEDTAVYYCNVKDIDAEAYAYDYWGQGTQVTVS }\end{array}$ \\
\hline Sb\# 41 & $\begin{array}{l}\text { QVQLVESGGGLVQAGGSLRLSCAASGFPVYHVWMEWYRQAPGKEREWVAAITSSGSHTYYADSVK } \\
\text { GRFTISRDNAKNTVYLQMNSLKPEDTAVYYCNVKDSGQWRVQYDYWGQGTQVTVS }\end{array}$ \\
\hline Sb\#42 & $\begin{array}{l}\text { QVQLVESGGGLVQAGGSLRLSCAASGFPVYWHHMHWYRQAPGKEREWVAA I ISWGWYTTYADSVK } \\
\text { GRFTISRDNAKNTVYLQMNSLKPEDTAVYYCNVKDHGAQNQMYDYWGQGTQVTVS }\end{array}$ \\
\hline Sb\#45 & $\begin{array}{l}\text { QVQLVESGGGLVQAGGSLRLSCAASGFPVYRDRMAWYRQAPGKEREWVAAIYSAGQQTRYADSVK } \\
\text { GRFTISRDNAKNTVYLQMNSLKPEDTAVYYCNVKDVGHHYEYYDYWGQGTQVTVS }\end{array}$ \\
\hline Sb\# 46 & $\begin{array}{l}\text { QVQLVESGGGLVQAGGSLRLSCAASGFPVDNGYMHWYRQAPGKEREWVAA I DSYGWHTIYADSVK } \\
\text { GRFTISRDNAKNTVYLQMNSLKPEDTAVYYCNVKDKGQMRAAYDYWGQGTQVTVS }\end{array}$ \\
\hline Sb\# 47 & $\begin{array}{l}\text { QVQLVESGGGLVQAGGSLRLSCAASGFPVSWHSMYWYRQAPGKEREWVAAIFSEGDWTYYADSVK } \\
\text { GRFTISRDNAKNTVYLQMNSLKPEDTAVYYCNVKDYGSSYYKYDYWGQGTQVTVS }\end{array}$ \\
\hline Sb\# 48 & $\begin{array}{l}\text { QVQLVESGGGLVQAGGSLRLSCAASGFPVSQSVMAWYRQAPGKEREWVAAIYSKGQYTHYADSVK } \\
\text { GRFTISRDNAKNTVYLQMNSLKPEDTAVYYCNVKDAGSSYWDYDYWGQGTQVTVS }\end{array}$ \\
\hline Sb\# 49 & $\begin{array}{l}\text { QVQLVESGGGSVQAGGSLRLSCAASGS IGQ IEYLGWFRQAPGKEREGVAALNTWTGRTYYADSVK } \\
\text { GRFTVSLDNAKNTVYLQMNSLKPEDTALYYCAAARWGRTKPLNTYYYSYWGQGTPVTVS }\end{array}$ \\
\hline Sb\# 50 & $\begin{array}{l}\text { QVQLVESGGGSVQAGGSLRLSCAASGY I DKIVYLGWERQAPGKEREGVAALYTLSGHTYYADSVK } \\
\text { GRFTVSLDNAKNTVYLQMNSLKPEDTALYYCAAATEGHAHALYRLHYYWGQGTQVTVS }\end{array}$ \\
\hline Sb\# 51 & $\begin{array}{l}\text { QVQLVESGGGLVQAGGSLRLSCAASGFPVYQGEMHWYRQAPGKEREWVAA IRSTGVQTWYADSVK } \\
\text { GRFTISRDNAKNTVYLQMNSLKPEDTAVYYCRVWVGTHYFGQGTQVTVS }\end{array}$ \\
\hline Sb\# 52 & $\begin{array}{l}\text { QVQLVESGGGSVQAGGSLRLSCAASGNIQRIYYLGWFRQAPGKEREGVAALMTYTGHTYYADSVK } \\
\text { GRFTVSLDNAKNTVYLQMNSLKPEDTALYYCAAAYVGAENPLPYSMYGYWGQGTQVTVS }\end{array}$ \\
\hline Sb\# 53 & $\begin{array}{l}\text { QVQLVESGGGSVQAGGSLRLSCAASGQ I SH IKYLGWFRQAPGKEREGVAALITRWGQTYYADSVK } \\
\text { GRFTVSLDNAKNTVYLQMNSLKPEDTALYYCAAADYGASDPLWF I HYLYWGQGTQVTVS }\end{array}$ \\
\hline Sb\# 55 & $\begin{array}{l}\text { QVQLVESGGGSVQAGGSLRLSCAASGKIWTIKYLGWERQAPGKEREGVAALMTRWGYTYYADSVK } \\
\text { GRFTVSLDNAKNTVYLQMNSLKPEDTALYYCAAANYGSNFPLAEEDYWYWGQGTQVTVS }\end{array}$ \\
\hline Sb\# 56 & $\begin{array}{l}\text { QVQLVESGGGSVQAGGSLRLSCAASGNISQIHYLGWFRQAPGKEREGVAALNTDYGYTYYADSVK } \\
\text { GRFTVSLDNAKNTVYLQMNSLKPEDTALYYCAAAYYFGDDI PLWWEAYSYWGQGTQVTVS }\end{array}$ \\
\hline Sb\# 58 & $\begin{array}{l}\text { QVQLVESGGGSVQAGGSLRLSCAASGN ISTIEYLGWFRQAPGKEREGVAALYTWHGQTYYADSVK } \\
\text { GRFTVSLDNAKNTVYLQMNSLKPEDTALYYCAAARWGRHMPLSATEYSYWGQGTQVTVS }\end{array}$ \\
\hline Sb\# 59 & $\begin{array}{l}\text { QVQLVESGGGSVQAGGSLRLSCAASGN IES IYYLGWERQAPGKEREGVAALWTGDGETYYADSVK } \\
\text { GRFTVSLDNAKNTVYLQMNSLKPEDTALYYCAAAAWGNSAPLTTYRYYYWGQGTQVTVS }\end{array}$ \\
\hline Sb\# 61 & $\begin{array}{l}\text { QVQLVESGGGSVQAGGSLRLSCAASGFIYGITYLGWFRQAPGKEREGVAALVTWNGQTYYADSVK } \\
\text { GRFTVSLDNAKNTVYLQMNSLKPEDTALYYCAAADWGYDWPLWDEWYWYWGQGTQVTVS }\end{array}$ \\
\hline Sb\# 62 & $\begin{array}{l}\text { QVQLVESGGGSVQAGGSLRLSCAASGTIADIKYLGWERQAPGKEREGVAALMTRWGSTYYADSVK } \\
\text { GRFTVSLDNAKNTVYLQMNSLKPEDTALYYCAAANYGANYPLYSQQYSYWGQGTQVTVS }\end{array}$ \\
\hline Sb\# 63 & $\begin{array}{l}\text { QVQLVESGGGSVQAGGSLRLSCAASGS ISS IKYLGWFRQAPGKEREGVAALMTRWGMTYYADSVK } \\
\text { GRETVSLDNAKNTVYLQMNSLKPEDTALYYCAAANYGANEPLQYTHYNYWGQGTQVTVS }\end{array}$ \\
\hline Sb\# 64 & $\begin{array}{l}\text { QVQLVESGGGSVQAGGSLRLSCAASGE IES IFYLGWFRQAPGKEREGVAALYTYVGQTYYADSVK } \\
\text { GRFTVSLDNAKNTVYLQMNSLKPEDTALYYCAAASYGAAHPLS IMRYYYWGQGTQVTVS }\end{array}$ \\
\hline Sb\# 65 & $\begin{array}{l}\text { QVQLVESGGGSVQAGGSLRLSCAASGTIAH IKYLGWFRQAPGKEREGVAALMTKWGQTYYADSVK } \\
\text { GRFTVSLDNAKNTVYLQMNSLKPEDTALYYCAAASYGANFPLKASDYSYWGQGTQVTVS }\end{array}$ \\
\hline Sb\# 66 & $\begin{array}{l}\text { QVQLVESGGGSVQAGGSLRLSCAASGS IQAITYLGWFRQAPGKEREGVAALVTWNGQTYYADSVK } \\
\text { GRFTVSLDNAKNTVYLQMNSLKPEDTALYYCAAADWGYDWPLWDEWYWYWGQGTQVTVS }\end{array}$ \\
\hline
\end{tabular}


bioRxiv preprint doi: https://doi org/10.1101/2020.04 16.045419. this version posted May 16.2020. The copyright holder for this preprin (which was not certified by peer review) is the author/funder, who has granted bioRxiv a license to display the preprint in perpetuity. It is made available under aCC-BY 4.0 International license.

\begin{tabular}{|l|l|}
\hline Sb\# 67 & $\begin{array}{l}\text { QVQLVESGGGSVQAGGSLRLSCAASGS ISS ITYLGWFRQAPGKEREGVAALVTYSGNTYYADSVK } \\
\text { GRFTVSLDNAKNTVYLQMNSLKPEDTALYYCAAATWGHSWPLYNDEYWYWGQGSQVTVS }\end{array}$ \\
\hline Sb\#68 & QVQLVESGGGSVQAGGSLRLSCAASGS ISS ITYLGWFRQAPGKEREGVAALITVNGHTYYADSVK \\
& GRETVSLDNAKNTVYLQMNSLKPEDTALYYCAAAAWGYAWPLHQDDYWYWGQGTQVTVS \\
\hline Sb\# 69 & QVQLVESGGGSVQAGGSLRLSCAASGS ISS ITYLGWFRQAPGKEREGVAALNTFNGTTYYADSVK \\
& GRFTVSLDNAKNTVYLQMNSLKPEDTALYYCAAATWGYSWPLIAEYNWYWGQGTQVTVS \\
\hline Sb\#71 & QVQLVESGGGSVQAGGSLRLSCAASGS ISS ITYLGWFRQAPGKEREGVAALKTQAGFTYYADSVK \\
& GRFTVSLDNAKNTVYLQMNSLKPEDTALYYCAAANWGYSWPLYEADDWYWGQGTQVTVS \\
\hline
\end{tabular}

Table 3 - Purification details of top-performing sybodies, and kinetic parameters for sybody interactions with SARS-CoV-2 proteins

\begin{tabular}{|c|c|c|c|c|c|}
\hline & $\begin{array}{l}\text { Elution Volume } \\
\qquad(\mathrm{ml})^{*}\end{array}$ & $\begin{array}{l}\text { Yield per } 50 \\
\text { ml (mg) }\end{array}$ & ka $\left(M^{-1} s^{-1}\right)^{*}$ & $\operatorname{kd}\left(s^{-1}\right)^{*}$ & $\mathrm{Kd}(\mathrm{nM}) *$ \\
\hline Sb\#14 & 11.51 & 0.94 & $\begin{array}{l}1.81 \pm 0.02 \mathrm{E} 5 \\
1.75 \pm 0.03 \mathrm{E} 5\end{array}$ & $\begin{array}{l}5.58 \pm 0.09 E-3 \\
3.62 \pm 0.10 E-3\end{array}$ & $\begin{array}{l}30.75 \\
20.67\end{array}$ \\
\hline Sb\#15 & 11.26 & 0.79 & $\begin{array}{l}3.00 \pm 0.05 E 5 \\
2.94 \pm 0.05 E 5\end{array}$ & $\begin{array}{l}7.27 \pm 0.13 \mathrm{E}-3 \\
6.47 \pm 0.11 \mathrm{E}-3\end{array}$ & $\begin{array}{l}24.22 \\
22.00\end{array}$ \\
\hline Sb\#16 & 12.64 & 0.72 & $\begin{array}{l}3.46 \pm 0.06 \mathrm{E} 5 \\
3.26 \pm 0.06 \mathrm{E} 5\end{array}$ & $\begin{array}{l}2.12 \pm 0.03 E-2 \\
1.60 \pm 0.02 E-2\end{array}$ & $\begin{array}{l}61.22 \\
49.04\end{array}$ \\
\hline Sb\#42 & 14.13 & 0.10 & $\begin{array}{l}4.35 \pm 0.08 \mathrm{E} 5 \\
5.03 \pm 0.14 \mathrm{E} 5\end{array}$ & $\begin{array}{l}7.75 \pm 0.16 E-2 \\
5.22 \pm 0.10 E-2\end{array}$ & $\begin{array}{l}178.21 \\
103.79\end{array}$ \\
\hline Sb\#45 & 11.29 & 1.22 & $\begin{array}{l}2.07 \pm 0.03 E 5 \\
2.63 \pm 0.04 E 5\end{array}$ & $\begin{array}{l}1.76 \pm 0.03 E-2 \\
1.49 \pm 0.03 E-2\end{array}$ & $\begin{array}{l}84.82 \\
56.52\end{array}$ \\
\hline Sb\#68 & 11.38 & 0.27 & $\begin{array}{l}1.71 \pm 0.03 E 5 \\
2.27 \pm 0.05 E 5\end{array}$ & $\begin{array}{l}2.02 \pm 0.03 E-2 \\
8.36 \pm 0.26 E-3\end{array}$ & $\begin{array}{c}118.12 \\
36.77\end{array}$ \\
\hline
\end{tabular}

*on a Sepax SRT-10C SEC100 column, ${ }^{*}$ upper value: RBD-vYFP, lower value: ECD

\section{DATA AVAILABILITY STATEMENT}

The plasmids encoding for the six highest affinity binders will very soon be available through Addgene (Addgene \#153522 - \#153527). 


\section{ACKNOWLEDGEMENTS}

We thank Rony Nehmé and André Heuer (Creoptix AG, Wädeswil, Switzerland) for the acquisition, fitting and interpretation of $\mathrm{GCl}$ measurements using the WAVEsystem. We thank Florence Projer, David Hacker and Kelvin Lau (Protein Production and Structure Core Facility, EPFL, Switzerland) for the production of the pre-fusion spike protein. We are grateful to Jason McLellan (The University of Texas at Austin, U.S.) for having provided the pre-fusion-stabilized soluble spike expression vector.

\section{REFERENCES}

1. Kwok, K.O., et al., Herd immunity - estimating the level required to halt the COVID-19 epidemics in affected countries. J Infect, 2020.

2. Liu, Y., et al., The reproductive number of COVID-19 is higher compared to SARS coronavirus. J Travel Med, 2020. 27(2).

3. Zhang, S., et al., Estimation of the reproductive number of novel coronavirus (COVID-19) and the probable outbreak size on the Diamond Princess cruise ship: A data-driven analysis. Int J Infect Dis, 2020. 93: p. 201-204.

4. Bai, Y., et al., Presumed Asymptomatic Carrier Transmission of COVID-19. JAMA, 2020.

5. Wu, J.T., et al., Estimating clinical severity of COVID-19 from the transmission dynamics in Wuhan, China. Nature Medicine, 2020: p. 1-5.

6. Wickramasinghe, N.C., et al., Predicting the Future Trajectory of COVID-19. Virology, 2020. 4(1).

7. Ahmed, S.F., A.A. Quadeer, and M.R. McKay, Preliminary Identification of Potential Vaccine Targets for the COVID-19 Coronavirus (SARS-CoV-2) Based on SARS-CoV Immunological Studies. Viruses, 2020. 12(3).

8. Chen, W.-H., et al., The SARS-CoV-2 vaccine pipeline: An overview. Current Tropical Medicine Reports, 2020: p. 1-4.

9. Mitja, O. and B. Clotet, Use of antiviral drugs to reduce COVID-19 transmission. Lancet Glob Health, 2020.

10. Wang, C., et al., A novel coronavirus outbreak of global health concern. Lancet, 2020. 395(10223): p. 470-473.

11. Menachery, V.D., et al., A SARS-like cluster of circulating bat coronaviruses shows potential for human emergence. Nat Med, 2015. 21(12): p. 1508-13.

12. Li, F., Structure, Function, and Evolution of Coronavirus Spike Proteins. Annu Rev Virol, 2016. 3(1): p. 237-261.

13. Wrapp, D., et al., Cryo-EM structure of the 2019-nCoV spike in the prefusion conformation. Science, 2020. 367(6483): p. 1260-1263.

14. Walls, A.C., et al., Structure, function, and antigenicity of the SARS-CoV-2 spike glycoprotein. Cell, 2020.

15. Hoffmann, M., et al., SARS-CoV-2 Cell Entry Depends on ACE2 and TMPRSS2 and Is Blocked by a Clinically Proven Protease Inhibitor. Cell, 2020. 
16. Hulswit, R.J.G., et al., Human coronaviruses OC43 and HKU1 bind to 9-O-acetylated sialic acids via a conserved receptor-binding site in spike protein domain A. Proc Natl Acad Sci U S A, 2019. 116(7): p. 2681-2690.

17. Kirchdoerfer, R.N., et al., Pre-fusion structure of a human coronavirus spike protein. Nature, 2016. 531(7592): p. 118-21.

18. Yuan, Y., et al., Cryo-EM structures of MERS-CoV and SARS-CoV spike glycoproteins reveal the dynamic receptor binding domains. Nat Commun, 2017. 8: p. 15092.

19. Harrison, S.C., Viral membrane fusion. Virology, 2015. 479-480: p. 498-507.

20. Walls, A.C., et al., Unexpected Receptor Functional Mimicry Elucidates Activation of Coronavirus Fusion. Cell, 2019. 176(5): p. 1026-1039 e15.

21. He, Y., et al., Identification of immunodominant sites on the spike protein of severe acute respiratory syndrome (SARS) coronavirus: implication for developing SARS diagnostics and vaccines. J Immunol, 2004. 173(6): p. 4050-7.

22. Du, L., et al., The spike protein of SARS-CoV--a target for vaccine and therapeutic development. Nat Rev Microbiol, 2009. 7(3): p. 226-36.

23. Berry, J.D., et al., Development and characterisation of neutralising monoclonal antibody to the SARS-coronavirus. J Virol Methods, 2004. 120(1): p. 87-96.

24. ter Meulen, J., et al., Human monoclonal antibody combination against SARS coronavirus: synergy and coverage of escape mutants. PLoS Med, 2006. 3(7): p. e237.

25. Jiang, L., et al., Potent neutralization of MERS-CoV by human neutralizing monoclonal antibodies to the viral spike glycoprotein. Sci Transl Med, 2014. 6(234): p. 234 ra59.

26. He, Y., et al., Cross-neutralization of human and palm civet severe acute respiratory syndrome coronaviruses by antibodies targeting the receptor-binding domain of spike protein. J Immunol, 2006. 176(10): p. 6085-92.

27. He, Y., et al., Receptor-binding domain of severe acute respiratory syndrome coronavirus spike protein contains multiple conformation-dependent epitopes that induce highly potent neutralizing antibodies. J Immunol, 2005. 174(8): p. 4908-15.

28. Zhao, G., et al., A Novel Nanobody Targeting Middle East Respiratory Syndrome Coronavirus (MERS-CoV) Receptor-Binding Domain Has Potent Cross-Neutralizing Activity and Protective Efficacy against MERS-CoV. J Virol, 2018. 92(18).

29. Prabakaran, P., et al., Structure of severe acute respiratory syndrome coronavirus receptorbinding domain complexed with neutralizing antibody. J Biol Chem, 2006. 281(23): p. 1582936.

30. Wu, Y., et al., Fully human single-domain antibodies against SARS-CoV-2. bioRxiv, 2020.

31. Pallesen, J., et al., Immunogenicity and structures of a rationally designed prefusion MERSCoV spike antigen. Proc Natl Acad Sci U S A, 2017. 114(35): p. E7348-E7357.

32. Muyldermans, S., Nanobodies: natural single-domain antibodies. Annu Rev Biochem, 2013. 82: p. 775-97.

33. Pardon, E., et al., A general protocol for the generation of Nanobodies for structural biology. Nat Protoc, 2014. 9(3): p. 674-93.

34. Rasmussen, S.G., et al., Structure of a nanobody-stabilized active state of the beta(2) adrenoceptor. Nature, 2011. 469(7329): p. 175-80.

35. Zimmermann, I., et al., Synthetic single domain antibodies for the conformational trapping of membrane proteins. Elife, 2018. 7.

36. Zimmermann, I., et al., Generation of synthetic nanobodies against delicate proteins. Nat Protoc, 2020. 
37. Van Heeke, G., et al., Nanobodies ${ }^{\circledR}$ as inhaled biotherapeutics for lung diseases.

Pharmacology \& therapeutics, 2017. 169: p. 47-56.

38. Li, F., et al., Structure of SARS coronavirus spike receptor-binding domain complexed with receptor. Science, 2005. 309(5742): p. 1864-8.

39. Kirchhofer, A., et al., Modulation of protein properties in living cells using nanobodies. Nat Struct Mol Biol, 2010. 17(1): p. 133-8.

40. Kuhn, B.T., et al., Biotinylation of Membrane Proteins for Binder Selections. Methods Mol Biol, 2020. 2127: p. 151-165.

41. Egloff, P., et al., Engineered peptide barcodes for in-depth analyses of binding protein libraries. Nat Methods, 2019. 16(5): p. 421-428.

42. Attallah, C., et al., A highly efficient modified human serum albumin signal peptide to secrete proteins in cells derived from different mammalian species. Protein Expr Purif, 2017. 132: p. 27-33.

43. Geertsma, E.R. and R. Dutzler, A versatile and efficient high-throughput cloning tool for structural biology. Biochemistry, 2011. 50(15): p. 3272-8.

44. Brunner, J.D., et al., X-ray structure of a calcium-activated TMEM16 lipid scramblase. Nature, 2014. 516(7530): p. 207-12.

45. Nagai, T., et al., A variant of yellow fluorescent protein with fast and efficient maturation for cell-biological applications. Nature biotechnology, 2002. 20(1): p. 87-90.

46. Keefe, A.D., et al., One-step purification of recombinant proteins using a nanomolar-affinity streptavidin-binding peptide, the SBP-Tag. Protein expression and purification, 2001. 23(3): p. 440-446. 
bioRxiv preprint doi: https://doi org/10.1101/2020.04 16.045419; this version posted May 16,2020 . The copyright holder for this preprint (which was not certified by peer review) is the author/funder, who has granted bioRxiv a license to display the preprint in perpetuity. It is A
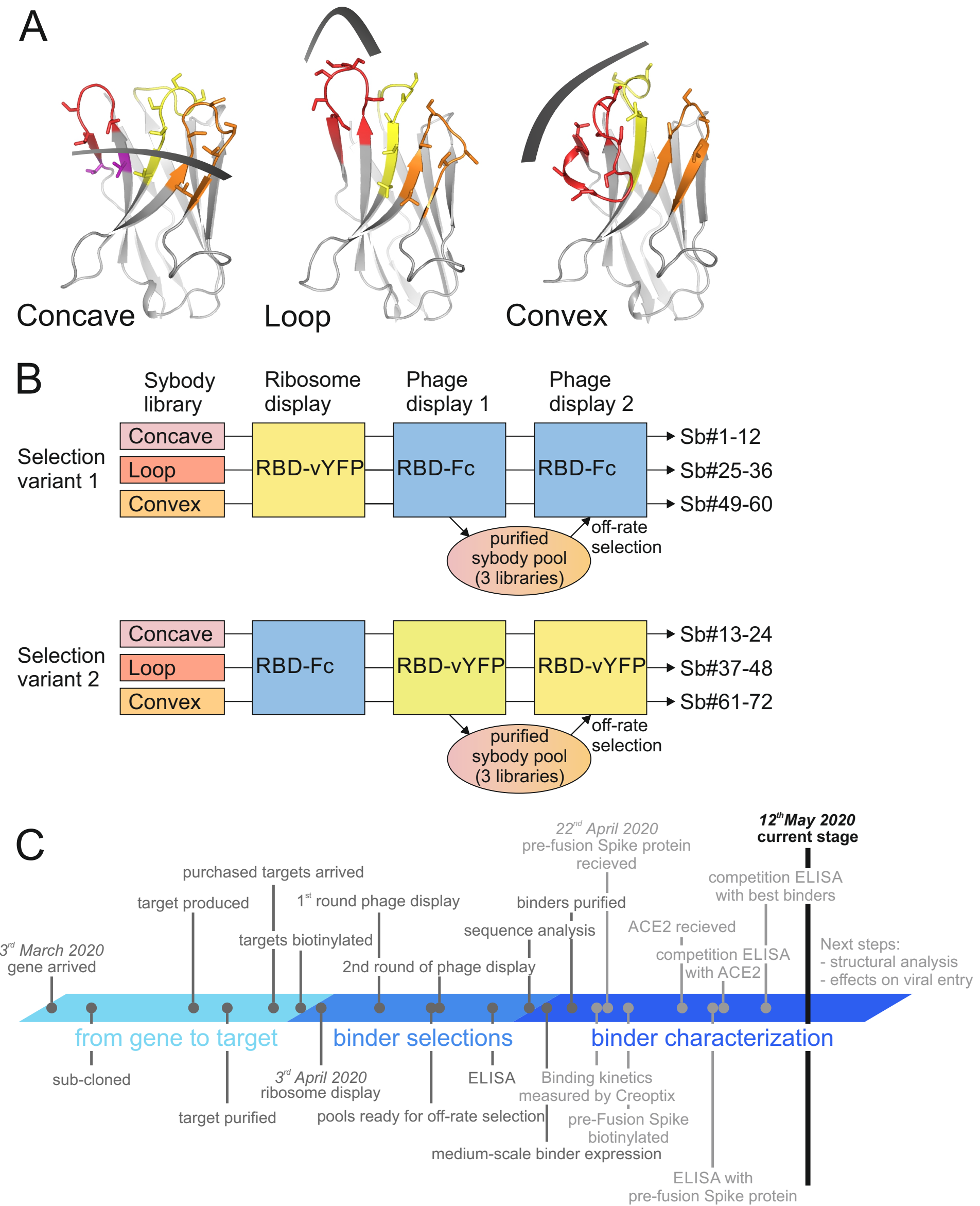

\section{Figure 1}

Sybody selections against SARS-CoV-2 RBDs. (A) Randomized surface of the three sybody libraries concave, loop and convex. CDR1 in yellow, CDR2 in orange, CDR3 in red. Randomized residues are depicted as sticks. (B) Selection scheme. A total of six independent selection reactions were carried out, including a target swap between ribosome display and phage display round. Enriched sybodies of phage display round 1 of all three libraries were expressed and purified as a pool and used to perform an off-rate selection in phage display round 2. (C) Time line of this sybody selection process. Please note that this is an intermediate report. 
bioRxiv preprint doi: https://doi.org/10.1101/2020.04.16.045419; this version posted May 16, 2020. The copyright holder for this preprint (which was not certified by peer review) is the author/funder, who has granted bioRxiv a license to display the preprint in perpetuity. It is made available under aCC-BY 4.0 International license.
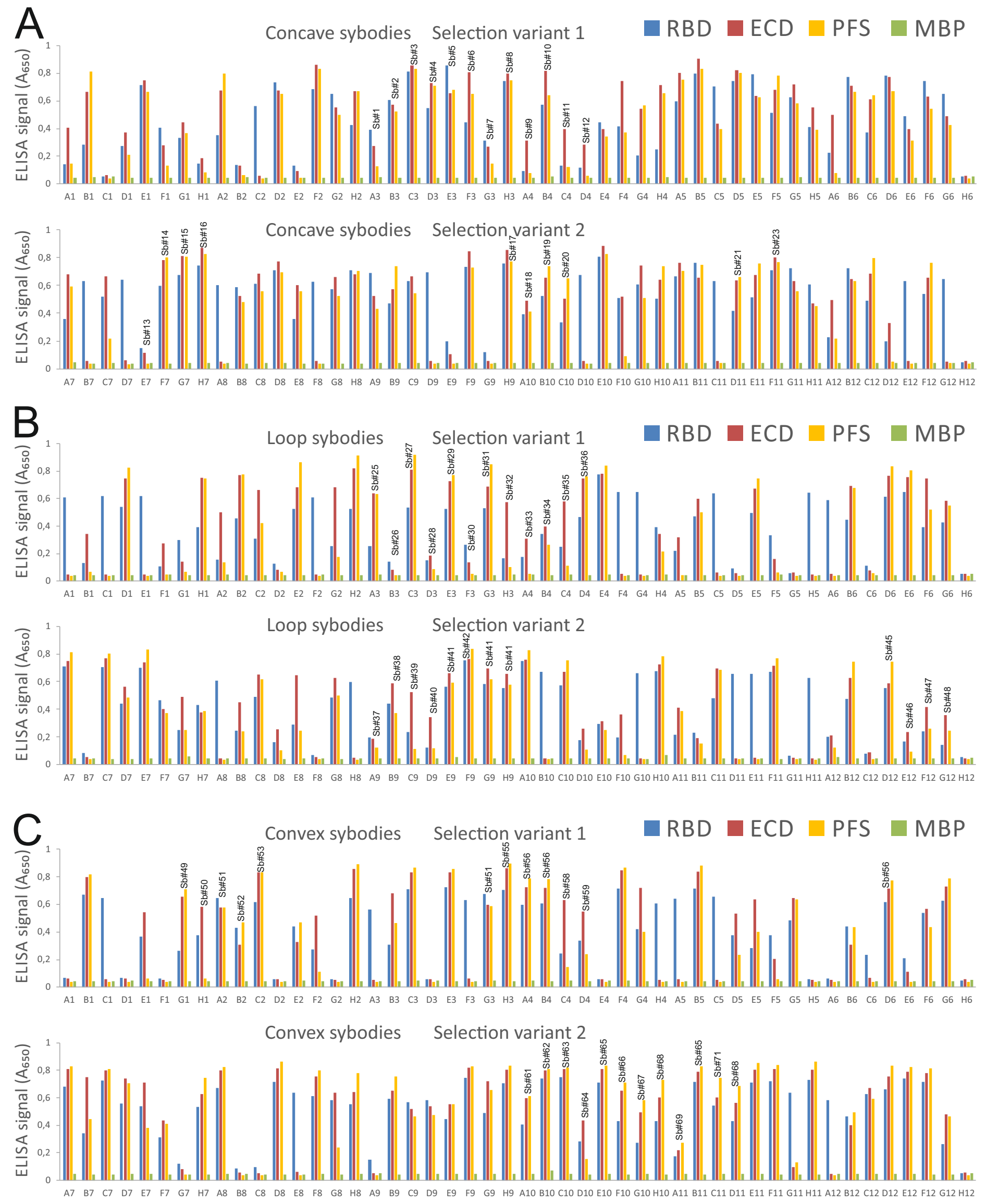

\section{Figure 2}

Sybody identification by ELISA. (A) Concave sybodies. (B) Loop sybodies. (C) Convex sybodies. For each of the six independent selection reactions, 47 clones were picked at random and analyzed by ELISA. A non-randomized sybody was used as negative control (wells $\mathrm{H} 6$ and $\mathrm{H} 12$, respectively). Sybodies that were sequenced are marked with the respective sybody name (Sb\#1-72). Please note that identical sybodies that were found 2-3 times are marked with the same sybody name (e.g. Sb\#41). ELISA analyses shown in these graphs were performed on three different days: (1) RBD and MBP, (2) $E C D,(3)$ PFS. 


\begin{tabular}{|c|c|c|}
\hline & & \\
\hline oncave & GFPVX்XXXMXWYRQÄPGKEREWVAÄIXSXG-XXTXY் & \\
\hline$S b \# 1$ & ...RKAN.H................ EQ.V. & \\
\hline$S b \# 2$ & . YQAN.H.............Y.-DG.H. & \\
\hline$b \# 3$ & 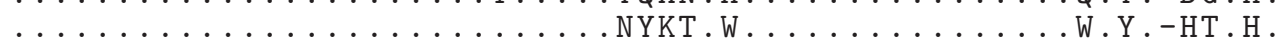 & \\
\hline$b \# 4$ & 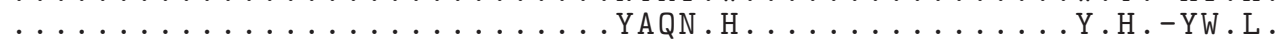 & \\
\hline$b \# 5$ & 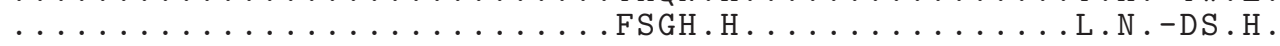 & \\
\hline$b \# 6$ & 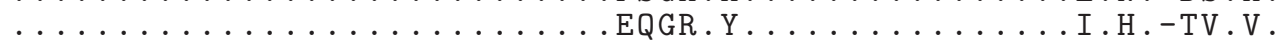 & \\
\hline$b \# 7$ & 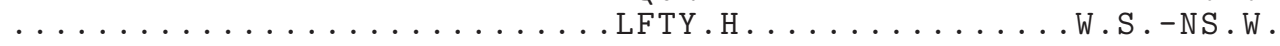 & \\
\hline$b \# 8$ & 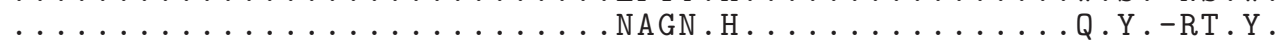 & \\
\hline$b \# 9$ & 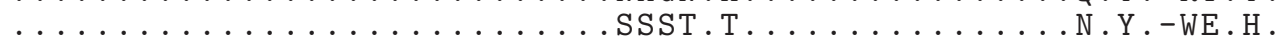 & \\
\hline$\neq 10$ & 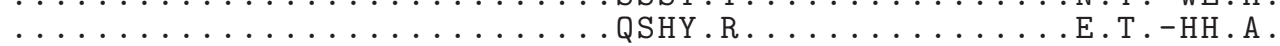 & \\
\hline 11 & 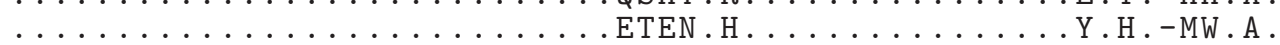 & \\
\hline 12 & 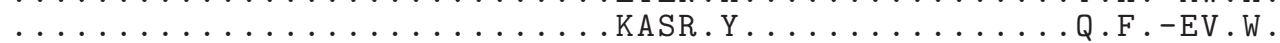 & \\
\hline 13 & 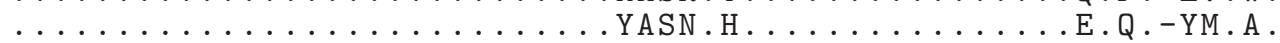 & \\
\hline 14 & $\ldots \ldots \ldots \ldots \ldots \ldots \ldots \ldots \ldots \ldots \ldots \ldots$ & \\
\hline 15 & 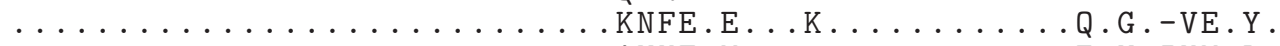 & \\
\hline 16 & 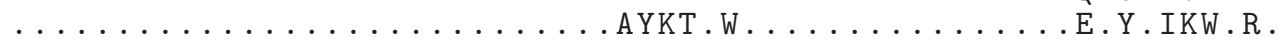 & \\
\hline \pm 17 & 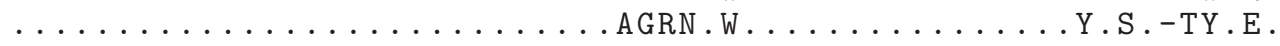 & \\
\hline$\neq 18$ & $\ldots \ldots \ldots \ldots \ldots \ldots \ldots \ldots \ldots \ldots \ldots \ldots \ldots \ldots$ & \\
\hline$\neq 19$ & 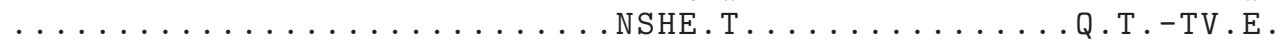 & \\
\hline$S b \# 20$ & 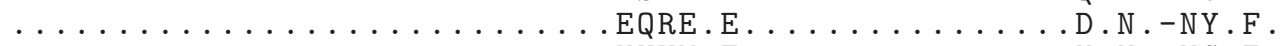 & \\
\hline$S b \# 21$ & $\ldots \ldots \ldots \ldots \ldots \ldots \ldots \ldots \ldots \ldots \ldots \ldots \ldots \ldots \ldots \ldots$ & \\
\hline$\neq 23$ & $\ldots \ldots \ldots \ldots \ldots \ldots \ldots \ldots \ldots \ldots \ldots \ldots$ & \\
\hline$b \# 51$ & $\ldots \ldots \ldots \ldots \ldots \ldots \ldots \ldots$. . . . . . . . . & \\
\hline & & \\
\hline
\end{tabular}

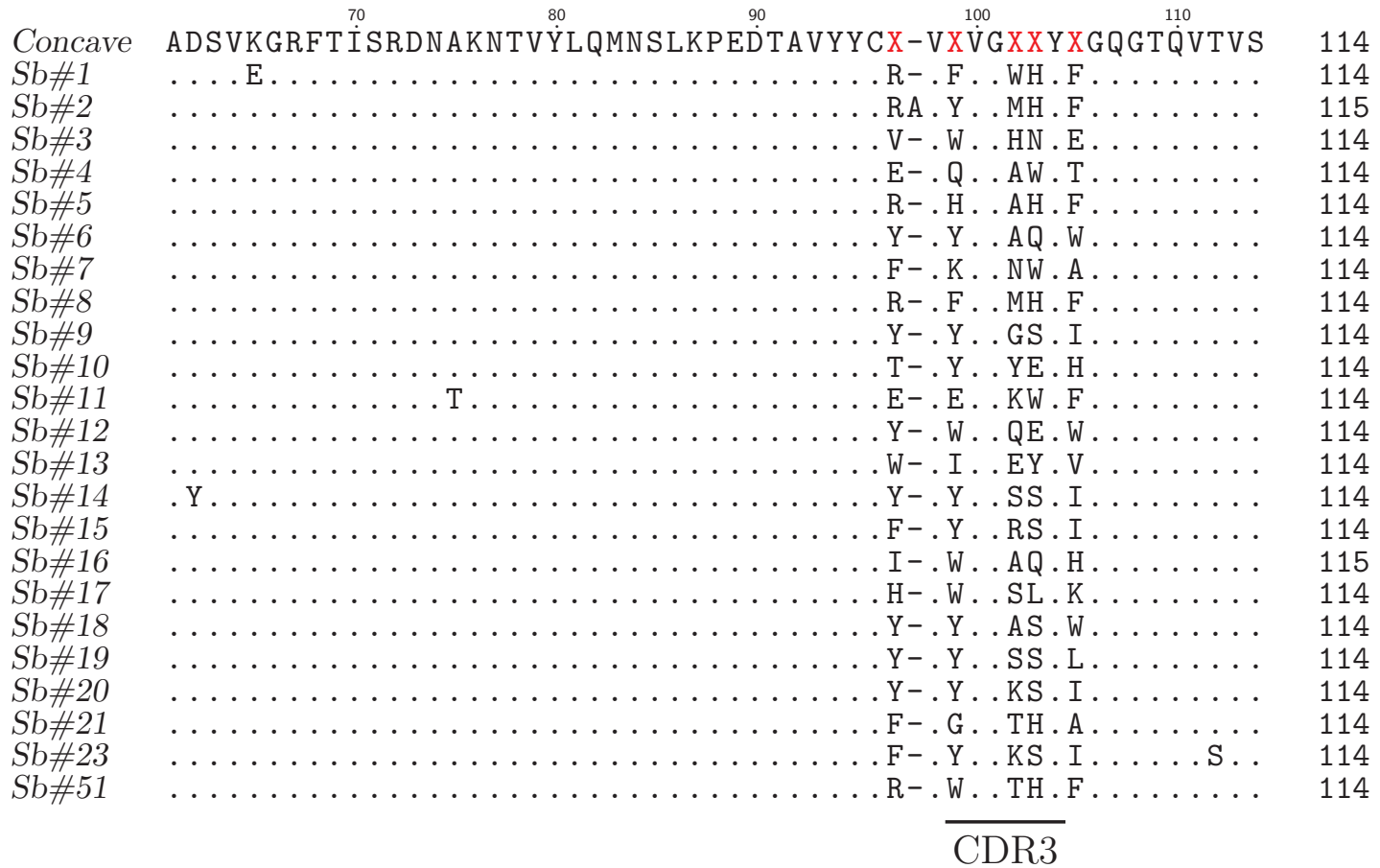

\section{Figure 3}

\section{Sequence alignment of concave RBD sybodies.}




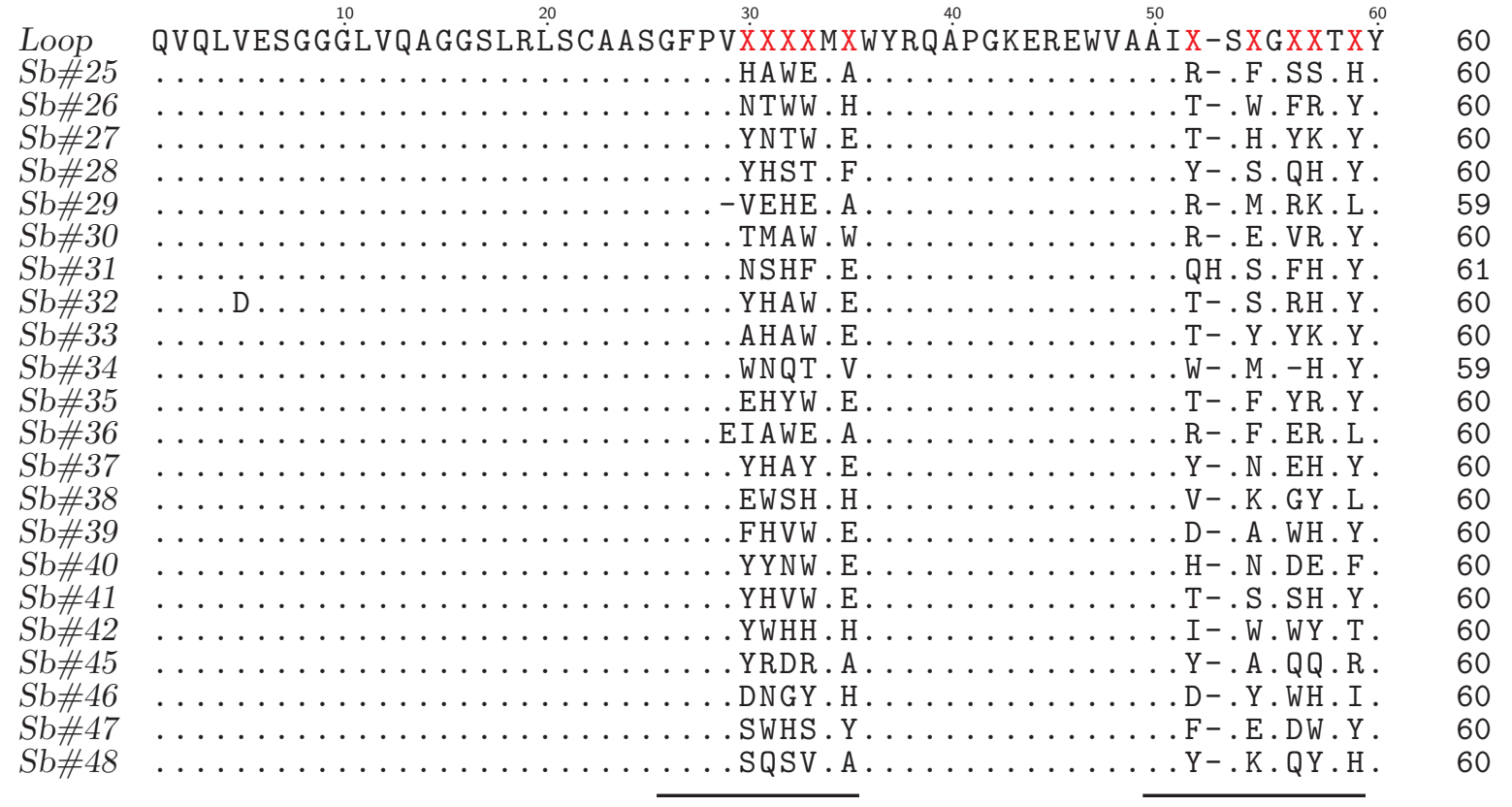

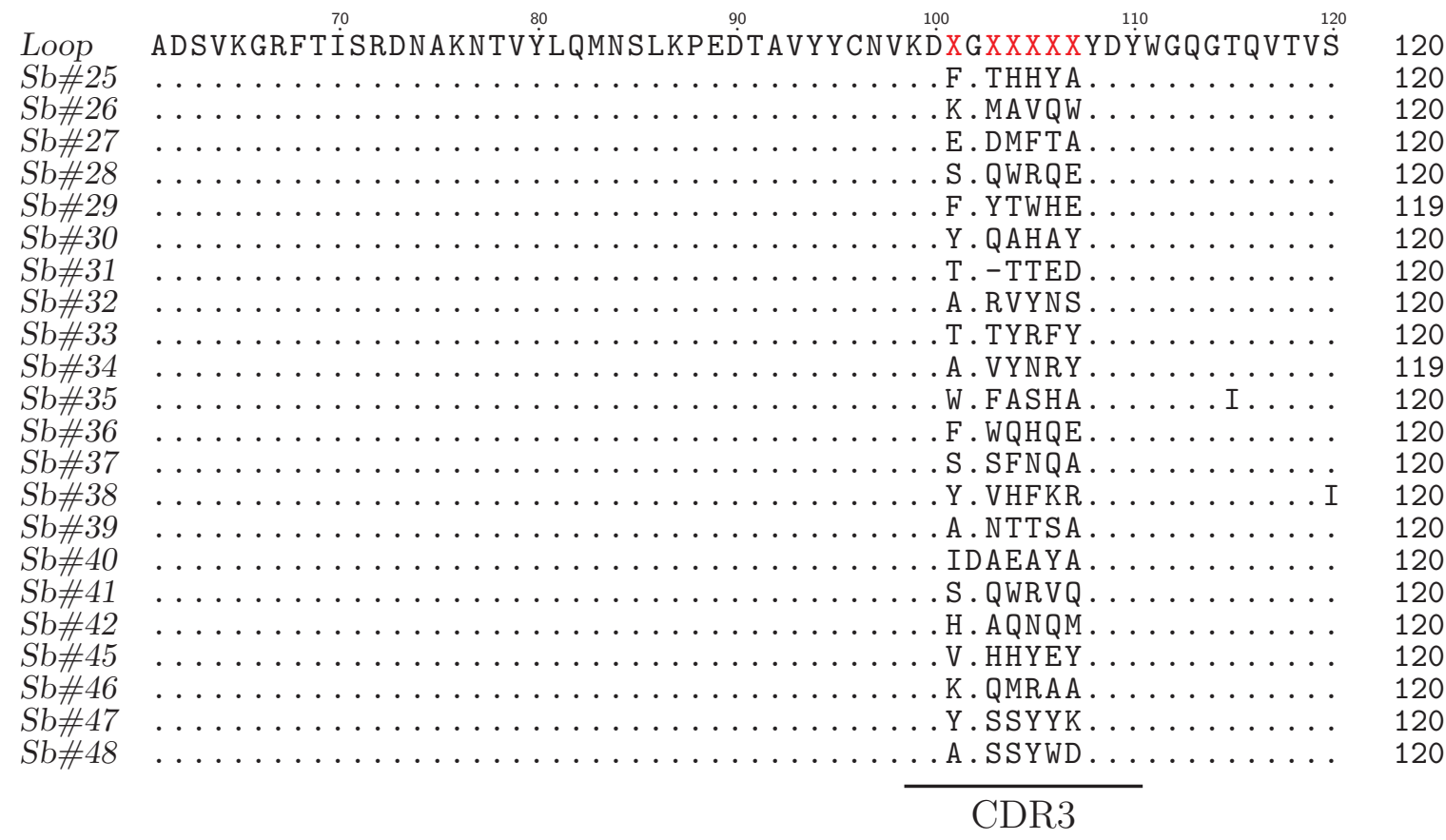

\section{Figure 4}

\section{Sequence alignment of loop RBD sybodies.}




\begin{tabular}{|c|c|}
\hline Convex & 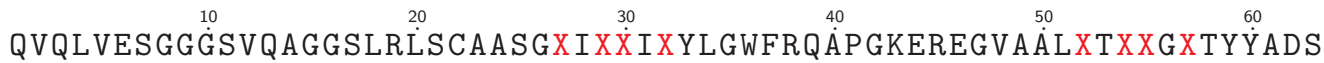 \\
\hline$S b \# 49$ & 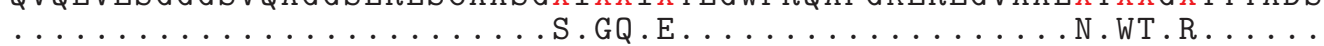 \\
\hline$S b \# 50$ & $\ldots$ Y.LS.H. . . \\
\hline$S b \# 52$ & . M.YT.H. \\
\hline$S b \# 53$ & $\ldots \ldots$...... \\
\hline$S b \# 55$ & $\ldots \ldots K . W T . K \ldots \ldots \ldots$ \\
\hline$S b \# 56$ & 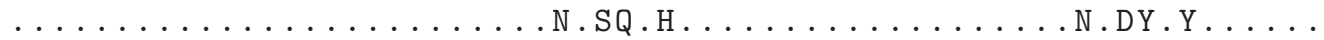 \\
\hline$S b \# 58$ & 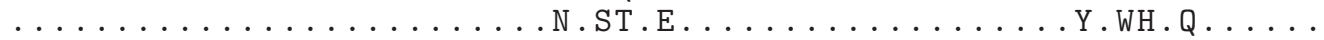 \\
\hline$S b \# 59$ & 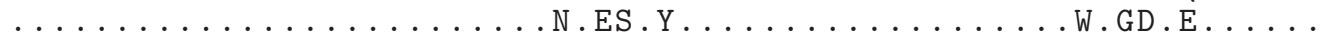 \\
\hline$S b \# 61$ & 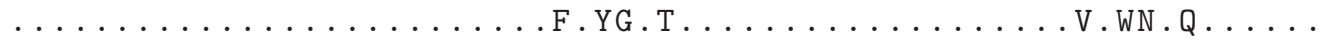 \\
\hline$S b \# 62$ & 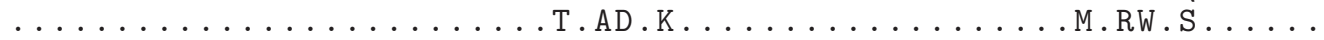 \\
\hline$S b \# 63$ & 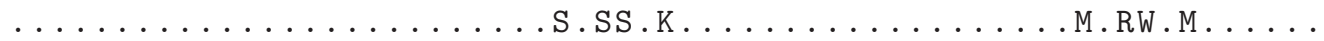 \\
\hline$S b \# 64$ & 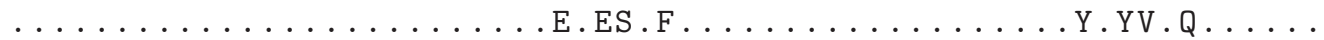 \\
\hline$S b \# 65$ & 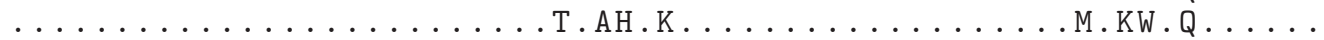 \\
\hline$S b \# 66$ & $\ldots \ldots \ldots \ldots \ldots \ldots \ldots \ldots \ldots \ldots \ldots \ldots \ldots$ \\
\hline$S b \# 67$ & 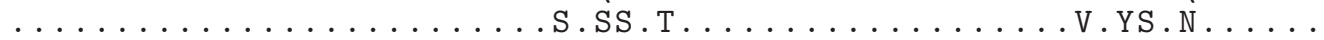 \\
\hline$S b \# 68$ & $\ldots \ldots \ldots \ldots \ldots \ldots \ldots \ldots \ldots \ldots \ldots \ldots$ \\
\hline 69 & 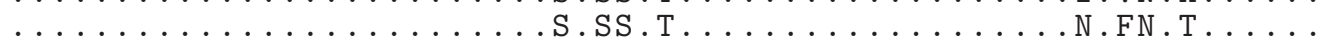 \\
\hline$b \# 71$ & $\ldots \ldots \ldots \ldots \ldots \ldots \ldots \ldots \ldots \ldots \ldots \ldots \ldots$ \\
\hline
\end{tabular}

\section{CDR1 CDR2}

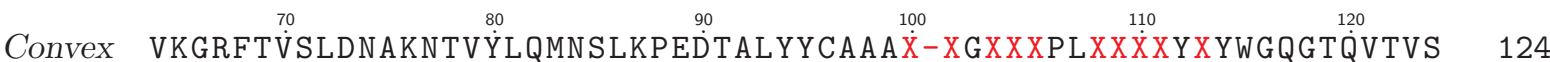

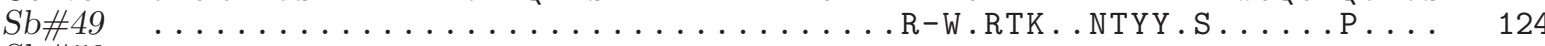

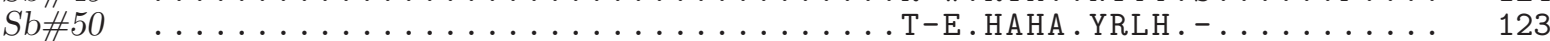

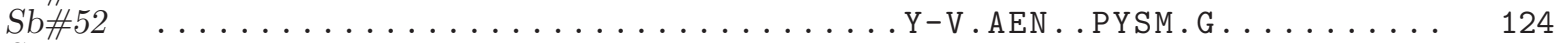

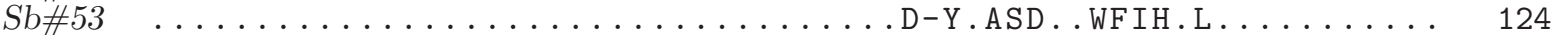

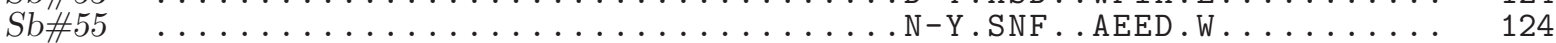

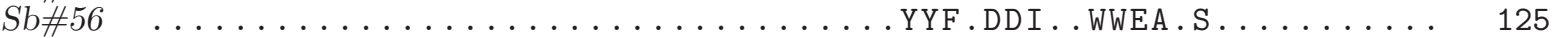

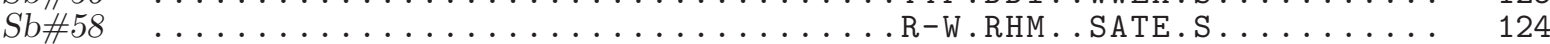

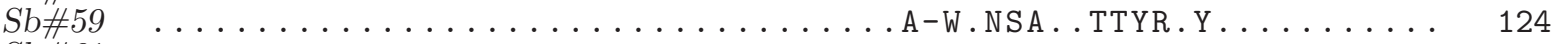

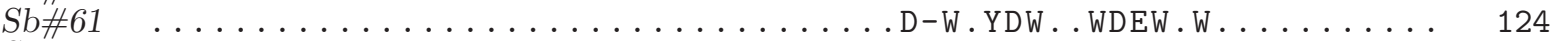

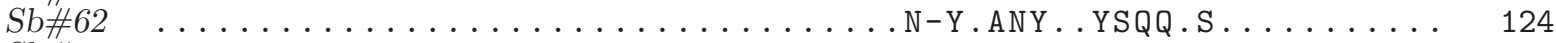

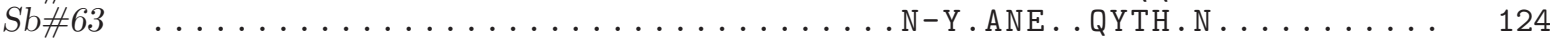

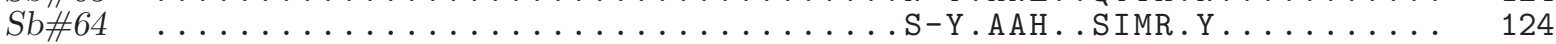

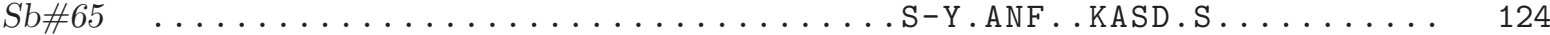

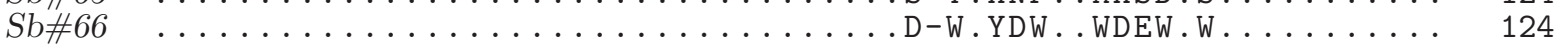

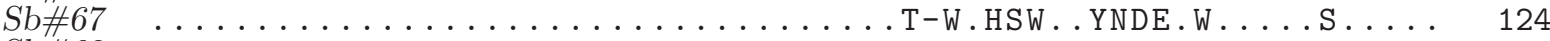

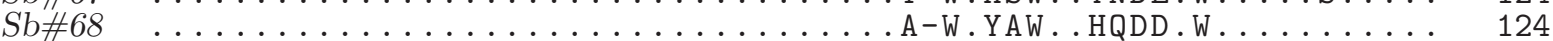

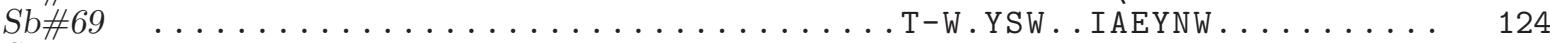

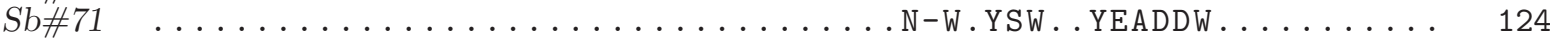

CDR3

\section{Figure 5}

Sequence alignment of convex RBD sybodies. 
bioRxiv preprint doi: https://doi org/10.1101/2020.04 16.045419; this version posted May 16, 2020. The copyright holder for this preprint (which was not certified by peer review) is the author/funder, who has granted bioRxiv a license to display the preprint in perpetuity. It is made available under aCC-BY 4.0 International license.

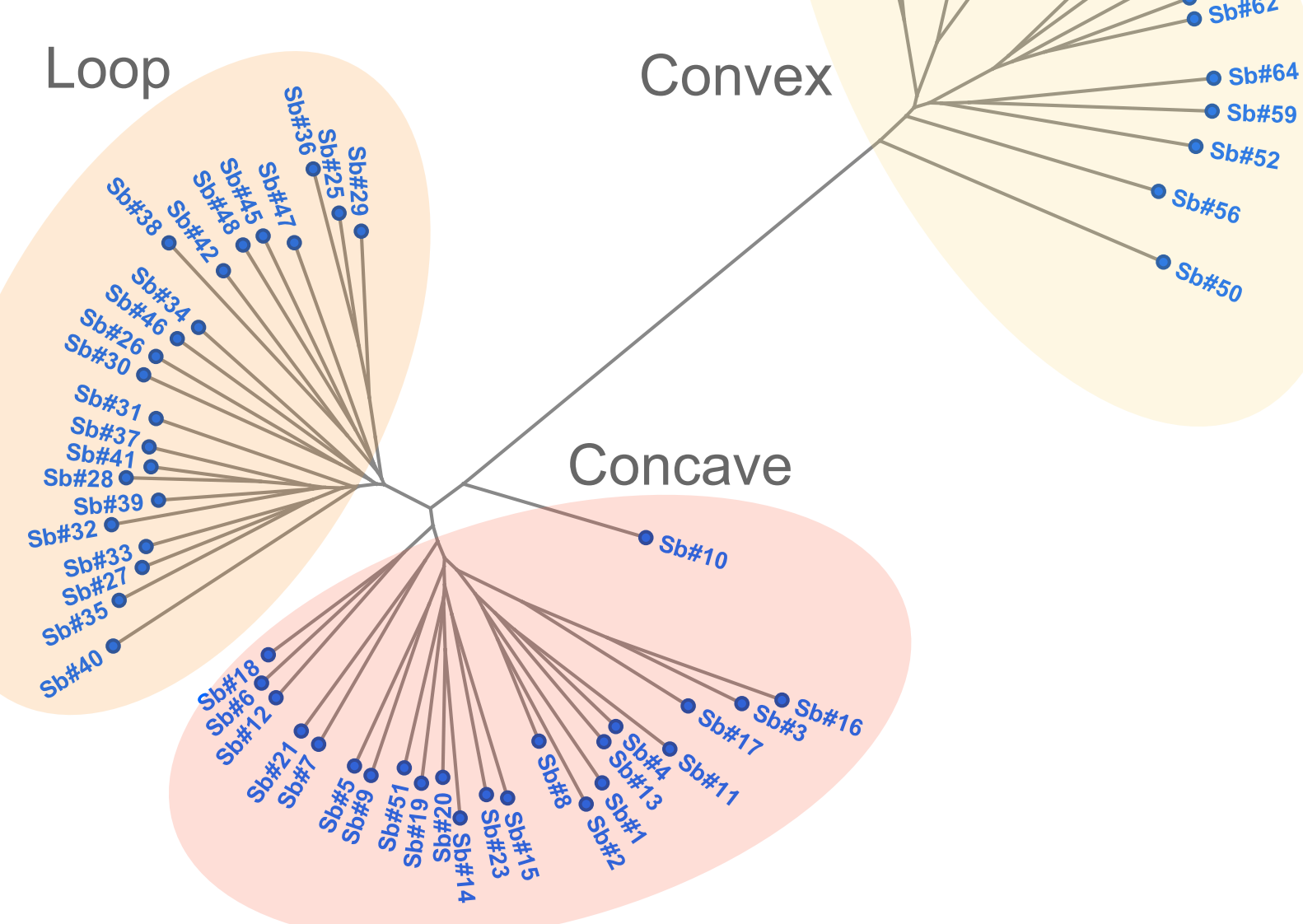

Figure 6

Phylogenetic tree of RBD sybodies. A radial tree was generated in CLC 8.1.3. 
bioRxiv preprint doi: https://doi org/10.1101/2020.04 16.045419; this version posted May 16, 2020. The copyright holder for this preprint (which was not certified by peer review) is the author/funder, who has granted bioRxiv a license to display the preprint in perpetuity. It is A

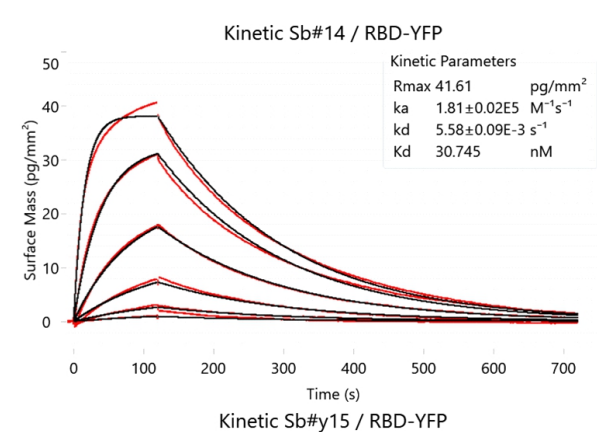
made available under aCC-BY 4.0 International license.
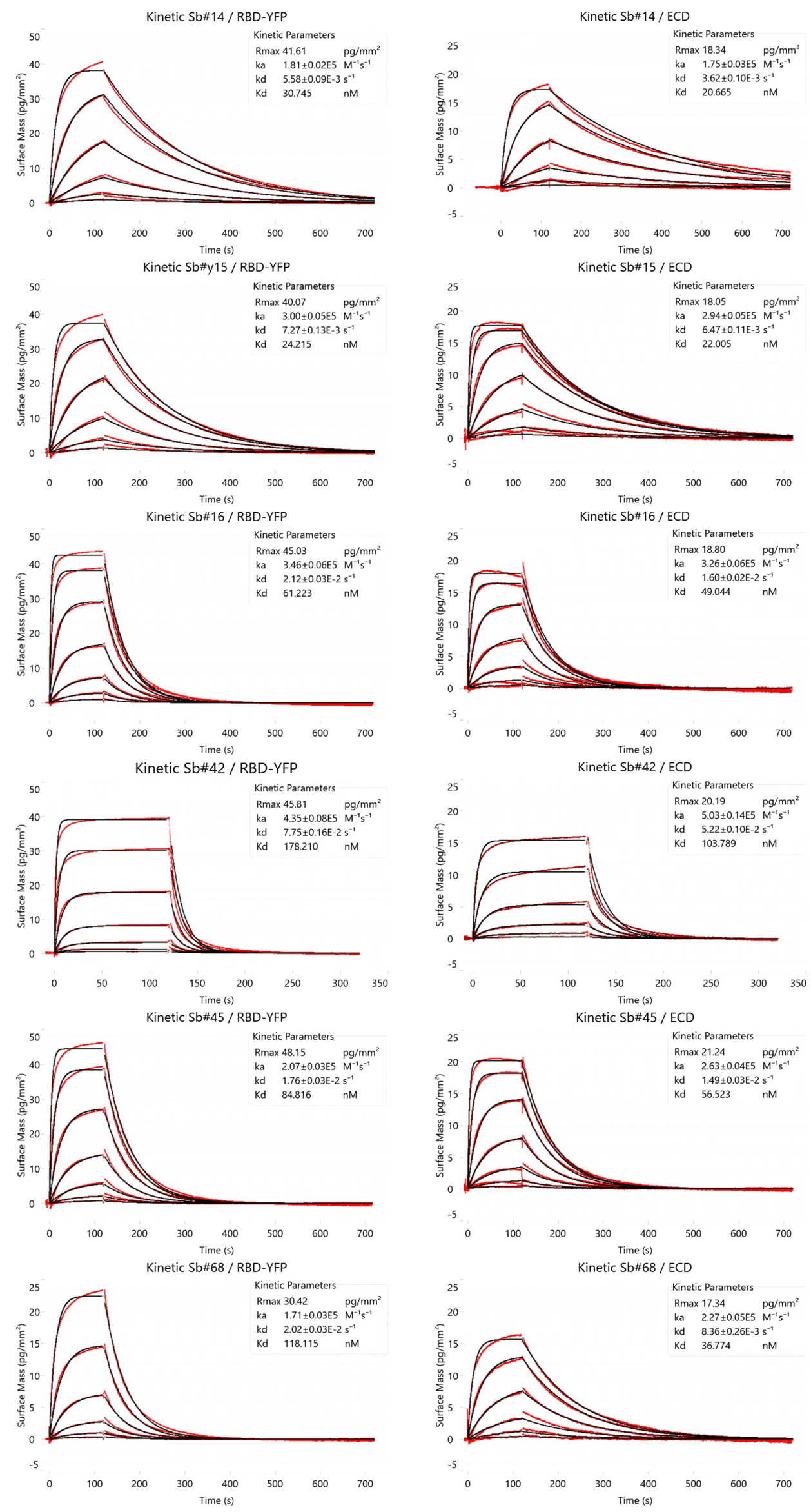

\section{Figure 7}

Kinetic characterization of the top six sybodies. (A) Binding kinetics were measured by grating-coupled interferometry on the WAVE system (Creoptix AG, Switzerland). RBD-VYFP and ECD were immobilized and the sybodies were injected at increasing concentrations ranging from $1.37 \mathrm{nM}$ to $1 \mu \mathrm{M}$. Data were fitted using a Langmuir 1:1 model. 
bioRxiv preprint doi: https $/ /$ doi org/10.1101/2020 04 16.045419; this version posted May 16,2020 . The copyright holder for this preprint (which was not certified by peer review) is the author/funder, who has granted bioRxiv a license to display the preprint in perpetuity. It is made available under aCC-BY 4.0 International license.

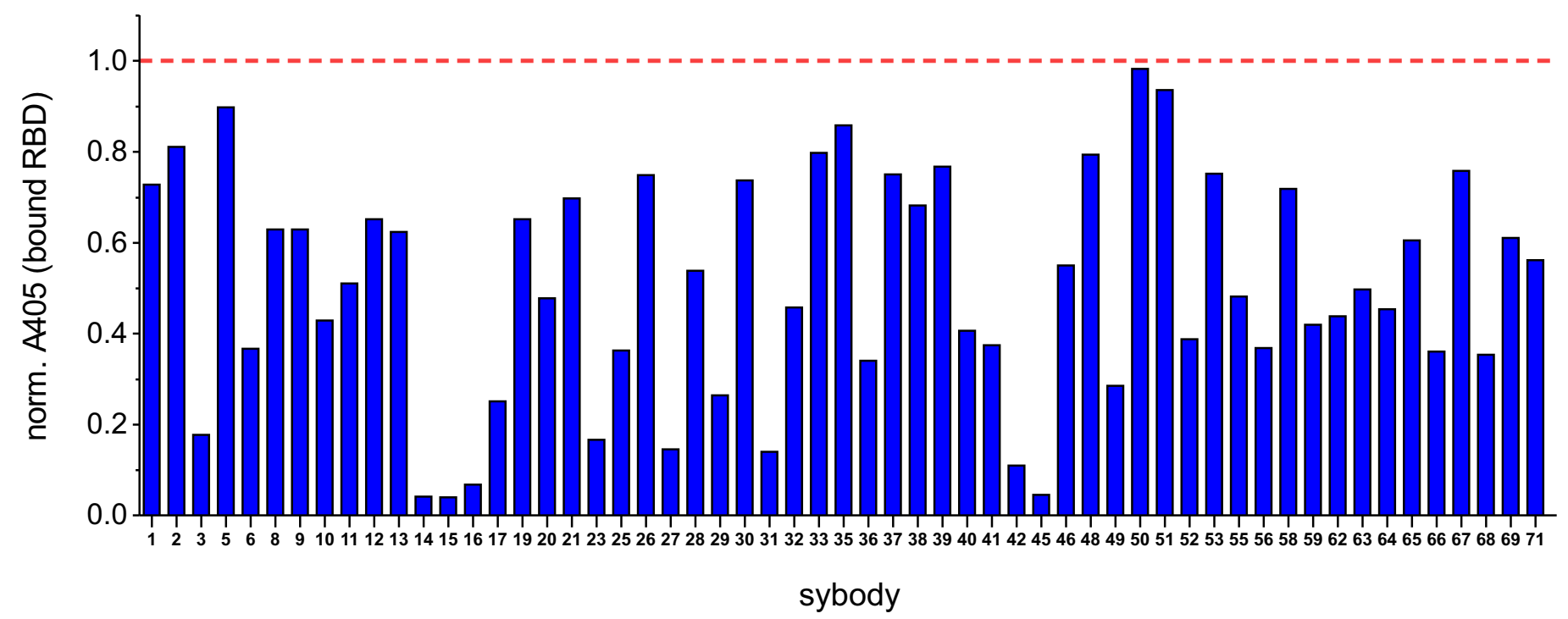

\section{Figure 8}

Sybodies inhibit RBD binding to ACE2. The effect of sybodies on RBD association with human ACE2 was assessed with an ELISA. Individual sybodies ( $500 \mathrm{nM}$, sybody number shown on X-axis) were incubated with biotinylated RBD-vYFP (25 nM) and the mixtures were exposed to immobilized ACE2. Bound RBD-vYFP was detected with streptavidin-peroxidase/TMB. Each column indicates background-subtracted absorbance at $405 \mathrm{~nm}$, normalized to the signal corresponding to RBD-vYFP in the absence of sybody (dashed red line). 
bioRxiv preprint doi: https://doi.org/10.1101/2020.04.16.045419; this version posted May 16, 2020. The copyright holder for this preprint (which was not certified by peer review) is the author/funder, who has granted bioRxiv a license to display the preprint in perpetuity. It is A made available under aCC-BY 4.0 International license.
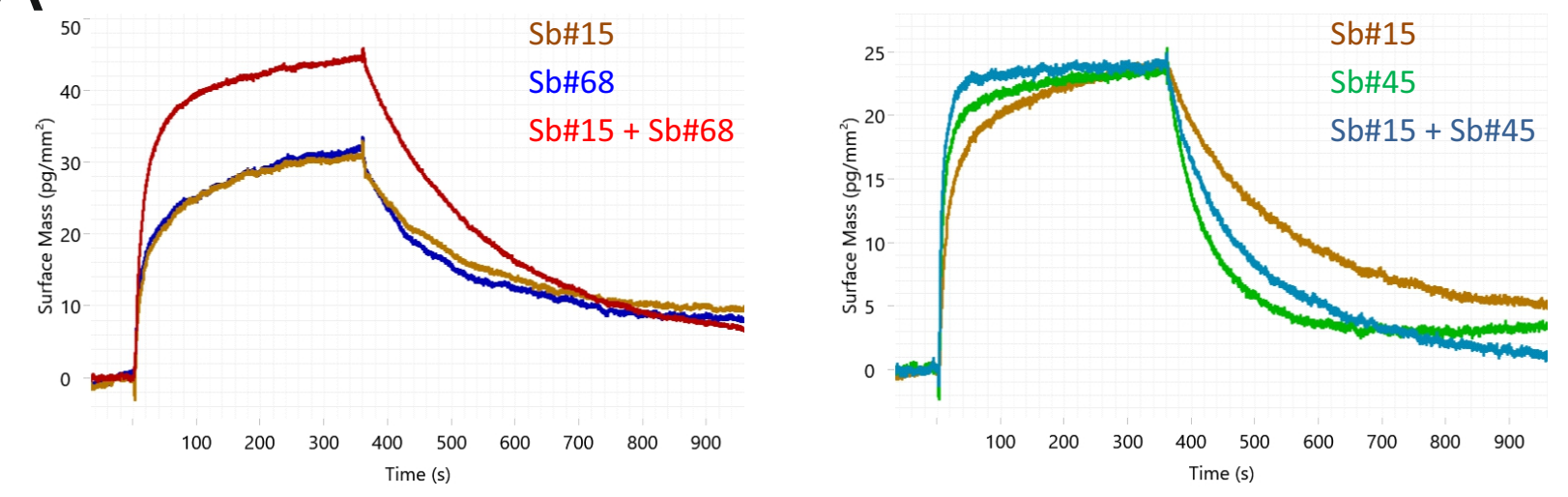

B

Sb\#15

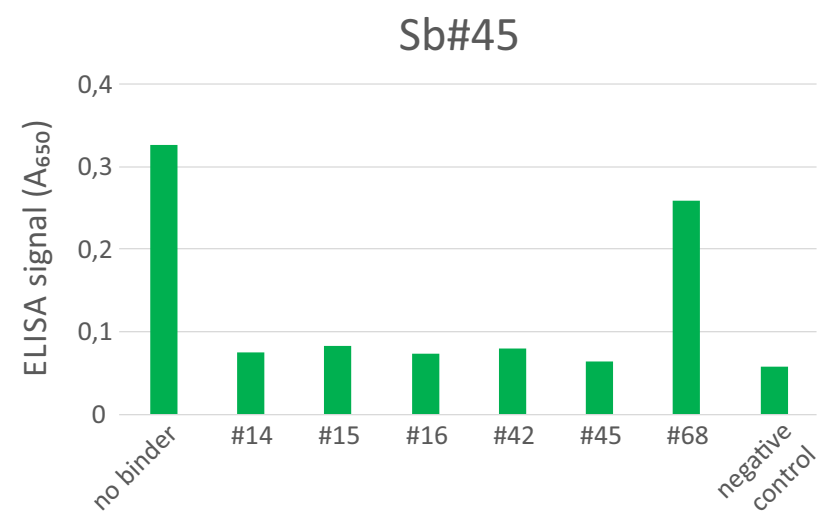

\section{Figure 9}

Simultaneous binding of Sb\#15 and Sb\#68. (A) Simultaneous binding of sybodies was analyzed using grating-coupled interferometry on the WAVE system (Creoptix AG, Switzerland). Biotinylated ECD was immobilized and the binders were injected alone and simultaneously at saturating concentrations (Sb\#15: $200 \mathrm{nM}$, Sb\#45: $500 \mathrm{nM}$, Sb\#68: 500 nM). Superimposed sensorgrams are shown. (B) Competition ELISA. Title of the graphs indicate the sybody which was directly coated on the plate at a concentration of $25 \mathrm{nM}$. The labels on the $x$-axes depict the sybody used for competition. To determine the background signal, buffer devoid of protein was added. 